\title{
Proposta de Procedimentos para Avaliação do Desempenho Térmico de Edificações (NBR 15575 e SiNAT) - Método Detalhado
}

\author{
Adriana Camargo de Brito \\ Elisa Morandé Sales \\ Fúlvio Vittorino \\ Marcelo de Mello Aquilino \\ Maria Akutsu
}

\section{Resumo das Etapas de Trabalho}

Neste capítulo, é apresentada uma proposta de aprimoramento do método detalhado para solução dos problemas encontrados na norma NBR 15575 (ABNT, 2013), que foram expostos no Capítulo 2. Para fundamentar a proposta, foram efetuadas as etapas indicadas nos itens 1.1 a 1.4. No item 2, é apresentada a proposta de procedimentos para a realização de avaliações pelo método detalhado.

\subsection{Temperatura do Solo}

Vários autores indicam a possibilidade de serem feitas correlaçóes entre valores da temperatura do ar e os valores da temperatura do solo (COSTA; GODOY, 1962; GOEDERT,1971; KUSUDA, 1965; ALFONSI; SENTELHAS, 1996; AZEVEDO; GALVANI, 2003; VILELA, 2004; USDOE, 2015; FLORIDES; KALOGIROU, 2004). Essas correlações tornam possível estimar o valor da temperatura do solo a partir da temperatura 
do ar do local, grandeza geralmente disponível com maior frequência em estaçôes meteorológicas.

Autores como Alfonsi e Sentelhas (1996) e Azevedo e Galvani (2003), apresentam equaçóes com a finalidade de se fazer o cálculo da temperatura do solo em cidades brasileiras, para várias profundidades, com base na temperatura média mensal do ar no local. Esses dados são utilizados para fins agrícolas, não havendo informaçôes sobre sua adequação em simulações da resposta térmica de edificaçôes.

Por outro lado, pré-processadores, como os do Energy Plus, o Basement e o Slab, são algumas das ferramentas mais avançadas para calcular valores da temperatura da superfície do solo em contato com o piso da edificação, a partir de simulaçóes iniciais, utilizando valores médios mensais da temperatura do solo, a $50 \mathrm{~cm}$ de profundidade, disponíveis no banco de dados do programa EnergyPlus, como indicado no manual do programa. Inclusive, o uso desses pré-processadores é recomendado pelo manual do RTQR, regulamento técnico que estabelece parâmetros para avaliação da eficiência energética de habitaçôes brasileiras. Entretanto, essa forma de se obter os dados de temperatura do solo ainda depende fortemente das decisôes do avaliador, fato que não satisfaz a necessidade de padronização de dados climáticos para utilização em simulaçôes relacionadas à avaliação de desempenho térmico de sistemas construtivos.

\subsubsection{Método}

A fim de verificar quais seriam os valores da temperatura do solo ou os mecanismos para estimá-la, foram efetuadas análises dos dados, disponíveis em literatura, referentes à temperatura do ar ou do solo em cidades brasileiras (INMET, 2015; USDOE, 2015; ABNT, 2013). Foram consideradas somente as cidades com dados disponíveis nessas três fontes para possibilitar comparaçóes, são elas: Belém - PA; Belo Horizonte - MG; Boa Vista - RR; Brasília - DF; Campo Grande - MS; Curitiba - PR; Florianópolis - SC; Fortaleza - CE; Manaus - AM; Porto Velho - RO; Recife - PE; Rio de Janeiro - RJ; Salvador - BA e São Paulo - SP. Além disso, foram utilizados mecanismos desenvolvidos por pesquisadores brasileiros, que permitem estimar a temperatura do solo com base na temperatura do ar (ALFONSI; SENTELHAS, 1996; AZEVEDO; GALVANI, 2003). 
A temperatura do solo, na sua superfície e em profundidades menores que $40 \mathrm{~cm}$, sofre influência direta do ambiente exterior, como indicado por vários autores (COSTA; GODOY, 1962; GOEDERT,1971; KUSUDA, 1965; ALFONSI; SENTELHAS, 1996; AZEVEDO; GALVANI, 2003; VILELA, 2004). Isso significa que a temperatura da superfície do solo em contato com a área construída pode ser afetada também pelo desempenho térmico da edificação. Nesse contexto, para proporcionar uma padronização dos dados de entrada em programas de simulaçôes da resposta térmica de edifícios, uma opção seria considerar valores de temperatura do solo em maior profundidade, por serem pouco afetados pelas variaçôes de parâmetros ambientais externos.

Desse modo, foi efetuada uma análise dos valores da temperatura do solo ou mecanismos para sua obtenção nas profundidades de $40 \mathrm{~cm}$ e $50 \mathrm{~cm}$ (considerando-se que a diferença de $10 \mathrm{~cm}$ náo produzirá alteraçóes significativas no valor de sua temperatura). Não foram contemplados dados referentes a profundidades maiores que $50 \mathrm{~cm}$, pois não há informaçóes em todas as fontes, impossibilitando análises comparativas.

Como o intuito é propor valores da temperatura do solo para dias típicos de projeto em períodos de verão e inverno, selecionaram-se os maiores e os menores valores da temperatura média mensal do ar, obtidos nas normais climatológicas do INMET (2015) e nos arquivos do USDOE (2015). Esses valores foram utilizados nas equaçôes de Alfonsi e Sentelhas (1996) e Azevedo e Galvani (2003) para obtenção da temperatura do solo em profundidade de $40 \mathrm{~cm}$.

Quanto às temperaturas do solo apresentadas por USDOE (2015), foram escolhidos os valores médios mensais dessa grandeza, em profundidade de $50 \mathrm{~cm}$, que correspondem aos meses em que há os maiores e os menores valores médios mensais da temperatura do ar. Efetuou-se esse procedimento, pois, geralmente, os valores da temperatura do solo são defasados em relação aos da temperatura do ar, devido à sua inércia térmica. Assim, os maiores valores da temperatura do solo não ocorrem, necessariamente, no mesmo mês em que há o maior valor da temperatura do ar. Na Figura 1, é apresentado um exemplo dessa ocorrência, a partir de valores das temperaturas médias mensais do solo e do ar obtidos no USDOE (2015) e temperaturas médias mensais do ar fornecidas pelo INMET (2015) para a cidade de São Paulo. 

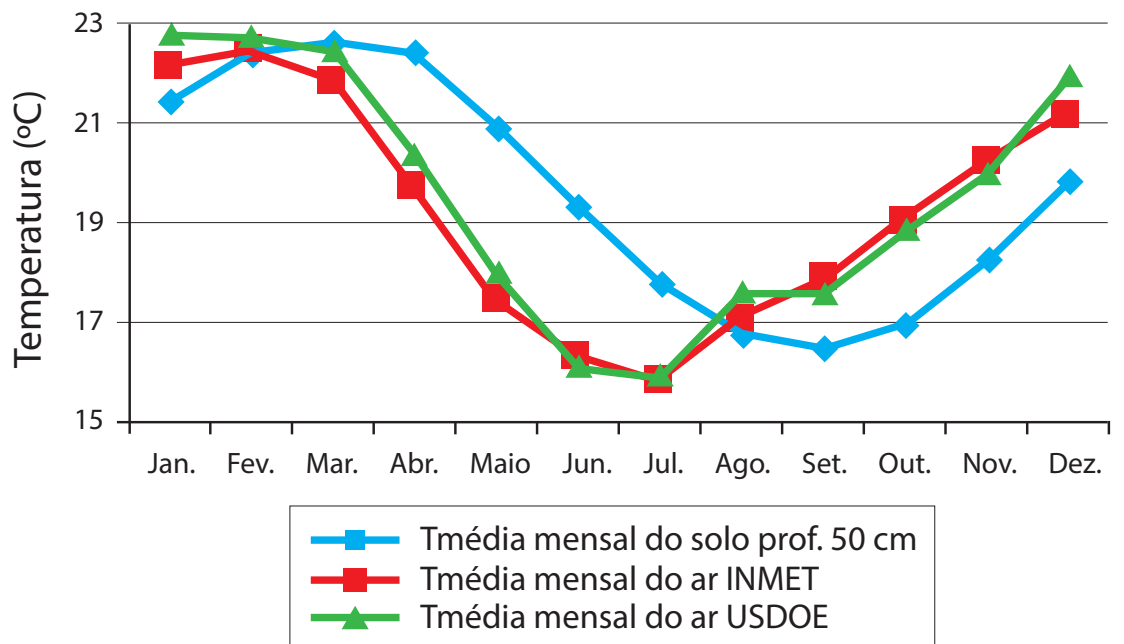

Figura 1. Temperaturas médias mensais do ar e do solo em São Paulo.

Na Figura 2, são apresentados os valores da temperatura do solo, resultantes das referidas equaçóes; as temperaturas médias mensais do solo em profundidade de $50 \mathrm{~cm}$, obtidas de USDOE (2015) e as temperaturas médias mensais do ar, conforme INMET (2015) e USDOE (2015). Na Figura 3, são apresentados os mesmo fatores para as temperaturas médias e mínimas do ar e do solo.

Os valores da temperatura do solo obtidos com as equaçóes de Alfonsi e Sentelhas (1996) são significativamente maiores do que os apresentados pelo USDOE (2015), ficando acima, inclusive, do valor médio da temperatura do ar, sendo extremos para uma profundidade de $40 \mathrm{~cm}$. Com as equaçóes de Azevedo e Galvani (2003), os valores da temperatura do solo são mais próximos daqueles indicados pelo USDOE (2015), apontando a possibilidade de sua eventual utilização a fim de gerar valores de temperatura do solo para serem usados em simulaçôes. Porém, dependendo da cidade, os valores para essa grandeza são maiores ou menores que os apresentados pelo USDOE (2015), não sendo possível identificar uma tendência.

Para a cidade de Sáo Paulo (Figuras 2 e 3), cujos dados de temperatura do solo foram medidos por Vilela (2004), identificou-se que os valores da temperatura média do solo em profundidade de $50 \mathrm{~cm}$, obtida por meio de interpolação de dados medidos pelo autor em outras profundidades, são da mesma ordem de grandeza dos valores apresentados pelo USDOE (2015). 


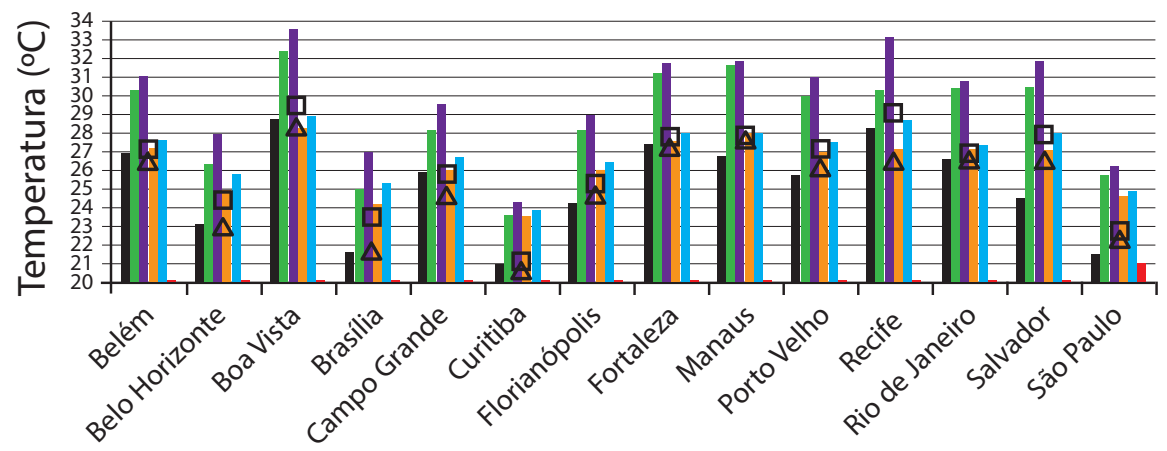

Tmédia solo mês com maior Tmédia ar USDOE

Alfonsi e Sentelhas - Tmédia ar USDOE

Azevedo e Galvani - Tmédia ar USDOE

$\Delta$ Maior Tmédia mensal ar INMET
Alfonsi e Sentelhas - Tmédia ar USDOE Azevedo e Galvani - Tmédia ar USDOE

Tmédia solo Vilela

口 Maior Tmédia mensal ar USDOE

Figura 2. Temp. solo prof. $40 \mathrm{~cm}$ com as equações; Maior. temp. média mensal solo prof. $50 \mathrm{~cm}$, USDOE (2015); Maior temp. média mensal do ar INMET (2015) e USDOE (2015).

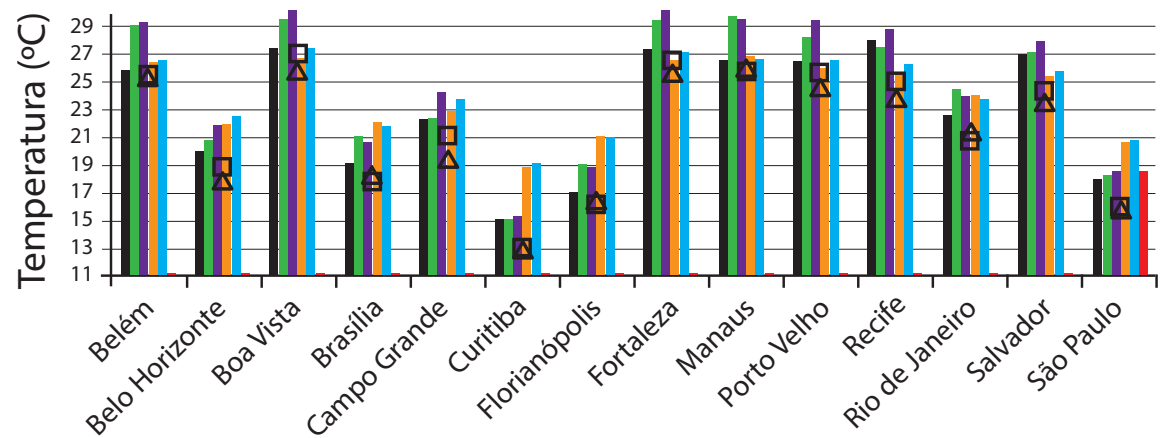

Tmédia solo mês com menor Tmédia ar USDOE

$\square$ Alfonsi e Sentelhas - Tmédia ar USDOE

Azevedo e Galvani - Tmédia ar USDOE

$\Delta$ Menor Tmédia mensal ar INMET
Alfonsi e Sentelhas - Tmédia ar INMET

Azevedo e Galvani - Tmédia ar INMET

Tmédia solo Vilela

口 Menor Tmédia mensal ar USDOE

Figura 3. Temp. solo prof. $40 \mathrm{~cm}$ com as equações (2003); Menor temp. média mensal solo prof. $50 \mathrm{~cm}$, USDOE (2016); Menor temp. média mensal do ar INMET (2015) e USDOE (2015). 
Observou-se uma relação entre os valores da temperatura média mensal do solo apresentados pelo USDOE (2015), em profundidade $50 \mathrm{~cm}$, e a temperatura média mensal do ar (INMET e USDOE). Porém, tal relação não é linear, não havendo dados suficientes para a obtenção de uma equação que a represente. As diferenças encontradas entre a temperatura média do solo e a temperatura média do ar variam de $0^{\circ} \mathrm{C}$ a $2^{\circ} \mathrm{C}$, dependendo da cidade, com exceção dos dados de Salvador, lugar em que essa diferença chega a $3,4^{\circ} \mathrm{C}$.

Os valores fornecidos pelo USDOE quanto à temperatura do solo são, geralmente, obtidos por cálculos (cujas equações não são indicadas nos documentos dos dados climáticos) e constituem, praticamente, a única referência que se tem dessa grandeza para a realização de simulaçóes computacionais da resposta térmica de edificaçôes. Em relação à cidade de São Paulo, para a qual há dados adicionais medidos por Vilela (2004), observa-se uma consistência dos dados calculados pelo USDOE para essa localidade, uma vez que pertencem à mesma ordem de grandeza de dados medidos, o que indica a adequação do método de cálculo para a obtenção de valores da temperatura do solo.

As equaçóes utilizadas para estimar a temperatura média do solo com base na temperatura média do ar, elaboradas por pesquisadores brasileiros (ALFONSI; SENTELHAS, 1996; AZEVEDO; GALVANI, 2003), não forneceram informaçóes adequadas para a realização de simulaçóes, seja por apresentarem valores extremos da temperatura do solo, seja por não haver uma tendência perceptível do comportamento dos dados obtidos em relaçáo aos dados de outras fontes (USDOE, 2015).

Por outro lado, identificou-se uma relação entre os valores da temperatura média do solo (USDOE, 2015) e a temperatura média do ar (USDOE, 2015; INMET, 2015), porém com uma variação significativa, que chega a $2^{\circ} \mathrm{C}$, de modo geral. Considerando-se a possibilidade de, eventualmente, na ausência de dados medidos da temperatura do solo, utilizar a temperatura média do ar para compor a temperatura do solo em profundidade de $50 \mathrm{~cm}$, seria necessário verificar qual o efeito que variaçóes da ordem de $2^{\circ} \mathrm{C}$ na temperatura do solo podem ter na resposta térmica da edificação. Outro fator a ser abordado é a forma de inserir os dados de temperatura do solo no programa computacional, fator que pode afetar de modo significativo o desempenho térmico dos recintos. Para elucidar esses 
fatores, foram efetuadas simulaçôes computacionais da resposta térmica de edificações em duas etapas, como descrito nos itens a seguir.

\section{Efeito da Temperatura do Solo e sua Profundidade}

Para verificar o efeito da temperatura do solo e da maneira de inserir esses dados no programa computacional, foram realizadas simulaçôes computacionais de uma habitação térrea típica de interesse social (CDHU, 1997), exposta às condições climáticas de dias típicos de verão e de inverno da cidade de São Paulo, presentes na Norma NBR 15575 (ABNT, 2013), com temperaturas do solo de $21^{\circ} \mathrm{C}$ a $34^{\circ} \mathrm{C}$ no verão e de $4^{\circ} \mathrm{C}$ a $18^{\circ} \mathrm{C}$ no inverno, com intervalos de $2^{\circ} \mathrm{C}$. Esses valores compreendem duas unidades a mais que a temperatura máxima diária e duas unidades a menos que a temperatura mínima diária nos dias típicos de projeto de verão e inverno. As características climáticas dos dias típicos são indicadas na Tabela 1. O piso da edificação foi simulado com esses valores de temperaturas superficial do solo e em profundidades de $50 \mathrm{~cm}$ e $100 \mathrm{~cm}$ do solo.

A edificação foi simulada com dois tipos de paredes: uma utilizando chapa cimentícia na face externa e gesso acartonado na face interna e a outra com $15 \mathrm{~cm}$ de concreto comum, intitulados sistemas leve e pesado, respectivamente. A cobertura da edificação tem forro de gesso acartonado e telhado constituído de telhas cerâmicas. As simulaçôes foram feitas com base na norma NBR 15575 (ABNT, 2013), com a edificação ventilada a uma taxa de $1 \mathrm{Ren} / \mathrm{h}$ e janelas sem sombreamento, voltadas à direção oeste no verão e sul no inverno. Foram analisados os dados obtidos para a sala.

\section{Adequação de Dados Disponíveis de Temperatura do Solo}

Para verificar a adequaçáo dos valores de temperatura do solo provenientes do USDOE (2015) e dos valores dessa grandeza adotandose a temperatura média mensal do ar (INMET, 2015), foram realizadas simulaçóes computacionais para reproduzir a resposta térmica de um protótipo, com dimensóes 3,3 $\mathrm{m} \times 4,3 \mathrm{~m}$, para o qual se dispóe de dados medidos conforme descrito a seguir. As paredes são feitas de tijolos de barro revestidos com argamassa em ambas as faces, a cobertura tem forro de madeira e telhado em telhas cerâmicas. A janela possui vidro simples e transparente, com dimensôes 1,2 $\mathrm{m} \times 1,2 \mathrm{~m}$, voltada para a direção sudeste, 
sem elementos de proteção solar e uma porta de madeira com dimensôes $0,8 \mathrm{~m} \times 2,1 \mathrm{~m}$.

O protótipo, construído no terreno do Instituto de Pesquisas Tecnológicas do estado de São Paulo - IPT, foi objeto de medições de parâmetros ambientais que incluem temperatura do ar externo, interno e temperaturas superficiais de teto, paredes e piso, em vários períodos, com as janelas e portas fechadas, não estando mais disponível por ter sido demolido em função de demandas internas do instituto. Os dados das mediçôes que foram selecionados correspondem ao terceiro dia de uma série de dias com características iguais, nos meses de abril e julho, que fazem parte de arquivo de medições do IPT.

A simulação da resposta térmica do protótipo foi obtida com a inserção de valores da temperatura do solo na superfície em contato com o piso da edificação e em profundidade de $50 \mathrm{~cm}$, utilizando valores da temperatura do solo a partir de dados contidos no documento do USDOE (2015) e da temperatura do ar fornecida pelo INMET (2015). Foram utilizados valores médios mensais da temperatura do ar e do solo, presentes nas referidas fontes, para cada mês em que foram realizadas as mediçôes (julho e abril). Os dados climáticos utilizados nas simulaçôes são indicados na Tabela 1 .

Tabela 1. Dados climáticos referentes aos dias das simulações.

\begin{tabular}{|c|c|c|c|c|c|}
\hline Dia & $\begin{array}{l}\text { Temp. } \\
\text { máx. ar } \\
\text { exterior } \\
\left.\quad{ }^{\circ} \mathrm{C}\right)\end{array}$ & $\begin{array}{l}\text { Temp. } \\
\text { mín. ar } \\
\text { exterior } \\
\left.\quad{ }^{\circ} \mathrm{C}\right)\end{array}$ & $\begin{array}{l}\text { Temp. } \\
\text { média ar } \\
\text { exterior } \\
\left({ }^{\circ} \mathrm{C}\right)\end{array}$ & $\begin{array}{c}\text { Radiação } \\
\text { solar global - } \\
\text { horizontal } \\
\left(\mathrm{W} / \mathrm{m}^{2}\right)\end{array}$ & $\begin{array}{l}\text { Temperatura } \\
\text { do soloc }\left({ }^{\circ} \mathrm{C}\right)\end{array}$ \\
\hline \multirow{2}{*}{$23 / a b r^{a}$} & \multirow{2}{*}{29,0} & \multirow{2}{*}{17,1} & \multirow{2}{*}{21,8} & \multirow{2}{*}{$3350^{b}$} & $\begin{array}{l}\text { 22,4 (Média do solo, abril, } \\
\text { USDOE, 2015) }\end{array}$ \\
\hline & & & & & $\begin{array}{l}\text { 19,7 (Média do ar, abril, } \\
\text { INMET, 2015) }\end{array}$ \\
\hline \multirow{2}{*}{ 19/jula } & \multirow{2}{*}{23,0} & \multirow{2}{*}{8,1} & \multirow{2}{*}{16,2} & \multirow{2}{*}{$2630^{b}$} & $\begin{array}{l}\text { 17,8 (Média do solo, julho, } \\
\text { USDOE, 2015) }\end{array}$ \\
\hline & & & & & $\begin{array}{l}\text { 15,8 (Média do ar, julho, } \\
\text { INMET, 2015) }\end{array}$ \\
\hline
\end{tabular}

${ }^{a}$ Dados obtidos por medições.

${ }^{\text {b}}$ Dados obtidos a partir do uso do programa EnergyPlus, com modelo de céu da ASHRAE e nebulosidade de $50 \%$, correspondente a céu parcialmente encoberto.

'Temperatura na superfície e em profundidade de $50 \mathrm{~cm}$. Solo com as seguintes características: condutividade térmica de $0,6 \mathrm{~W} /(\mathrm{m} . \mathrm{K})$, massa específica de $1700 \mathrm{~kg} / \mathrm{m}^{3}$ e calor específico de $840 \mathrm{~J} /$ (kg.K). 


\subsubsection{Resultados}

\section{Efeito da Temperatura do Solo e sua Profundidade}

$\mathrm{Na}$ Figura 4, são apresentados os valores máximos diários das temperaturas do ar interior da sala de uma habitação em São Paulo, com dois sistemas construtivos em função da temperatura do solo e sua profundidade e, na Figura 5, são indicados os mesmos parâmetros em relação à temperatura mínima do ar interior no dia típico de inverno.

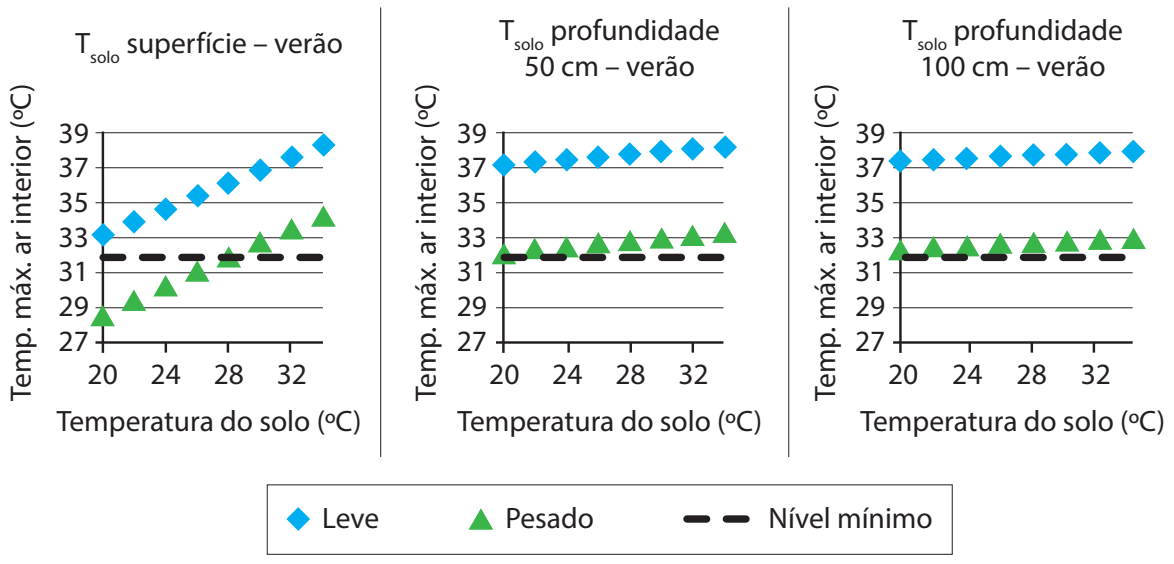

Figura 4. Temperatura máxima do ar interior de habitação em dia típico de verão com três sistemas construtivos em função da temperatura do solo em três profundidades.

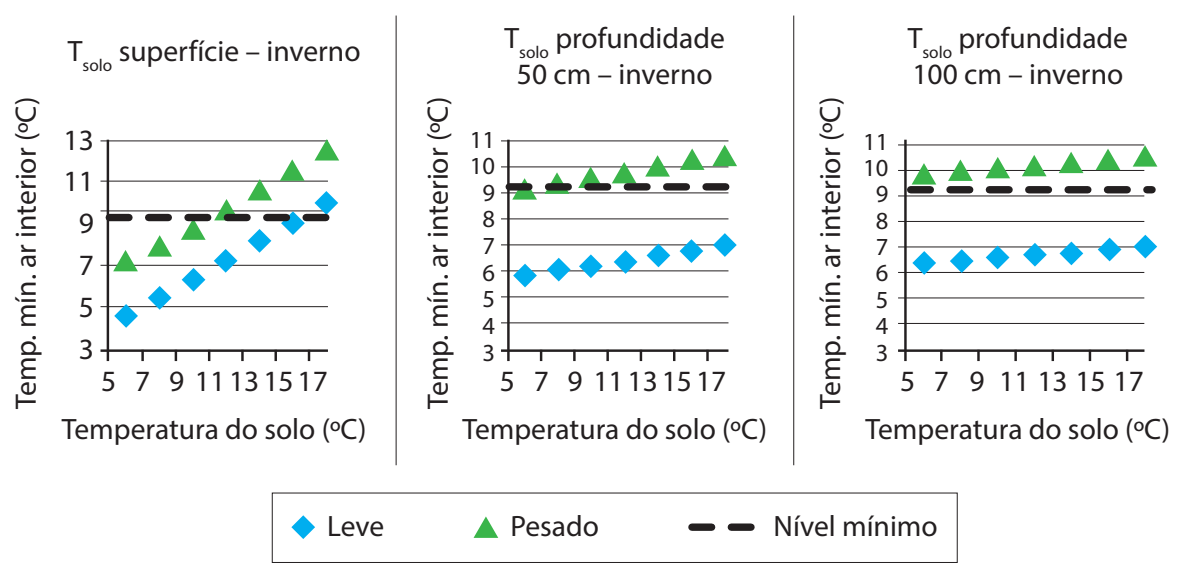

Figura 5. Temperatura mínima do ar interior de habitação em dia típico de inverno com três sistemas construtivos em função da temperatura do solo em três profundidades. 
Nas simulações em que a temperatura do solo é atribuída à superfície externa do piso, há um efeito significativo na temperatura máxima ou mínima do ar interior em comparação com os casos com temperatura do solo em profundidade de $50 \mathrm{~cm}$ ou $100 \mathrm{~cm}$. Uma variação de $2^{\circ} \mathrm{C}$ na temperatura superficial do solo produz uma alteraçáo da ordem de $1^{\circ} \mathrm{C}$ no valor da temperatura máxima ou mínima do ar interior com sistema pesado e $1,7^{\circ} \mathrm{C}$ com sistema leve. Isso repercute de modo mais significativo também no atendimento ao nível mínimo de desempenho térmico. Por outro lado, a mesma variaçáo de $2^{\circ} \mathrm{C}$ na temperatura do solo, mas simulada em profundidade de $50 \mathrm{~cm}$ e $100 \mathrm{~cm}$, resulta em alteraçáo menor que $0,2^{\circ} \mathrm{C}$. no valor da temperatura máxima ou mínima do ar interior.

\section{Adequação de Valores Disponíveis da Temperatura do Solo}

Nas Figuras 6 e 7, são apresentados os valores das temperaturas do ar externo, do ar interno e a temperatura superficial interna do piso, obtidos nas mediçóes e simulaçóes para dias em abril e julho, com valores de temperatura do solo provenientes de várias fontes, simulados em várias profundidades.

Nas simulações do dia 23 de abril (Figura 6), as temperaturas máximas do ar interior obtidas por simulaçóes diferem dos valores medidos de $0,6^{\circ} \mathrm{C}$ a $1,2^{\circ} \mathrm{C}$. A maior temperatura máxima do ar interior é obtida com dados de temperatura do solo do USDOE, em profundidade de $50 \mathrm{~cm}\left(25,2^{\circ} \mathrm{C}\right)$, e a menor, com a temperatura superficial do solo como a temperatura média mensal do ar, por meio do INMET $\left(19,7^{\circ} \mathrm{C}\right)$. Nas situaçóes com temperatura do solo em profundidade de $50 \mathrm{~cm}$ e com a temperatura superficial do solo oferecida pelo USDOE, as temperaturas máximas do ar interior apresentam a mesma ordem de grandeza (em torno de $25^{\circ} \mathrm{C}$ ), sendo a medida da temperatura máxima $24,2^{\circ} \mathrm{C}$. A temperatura superficial máxima do piso interno, nas simulaçóes, difere dos valores medidos com variação de $0,5^{\circ} \mathrm{C}$ a $1,3^{\circ} \mathrm{C}$. 


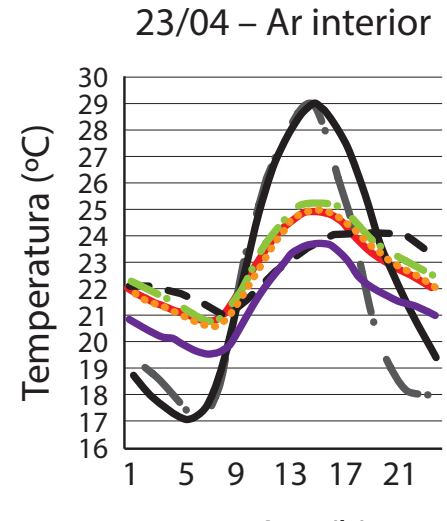

Horário (h)

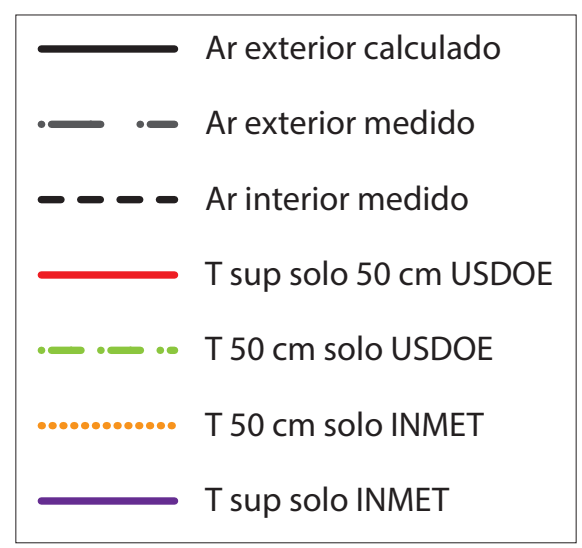

23/04 - Piso
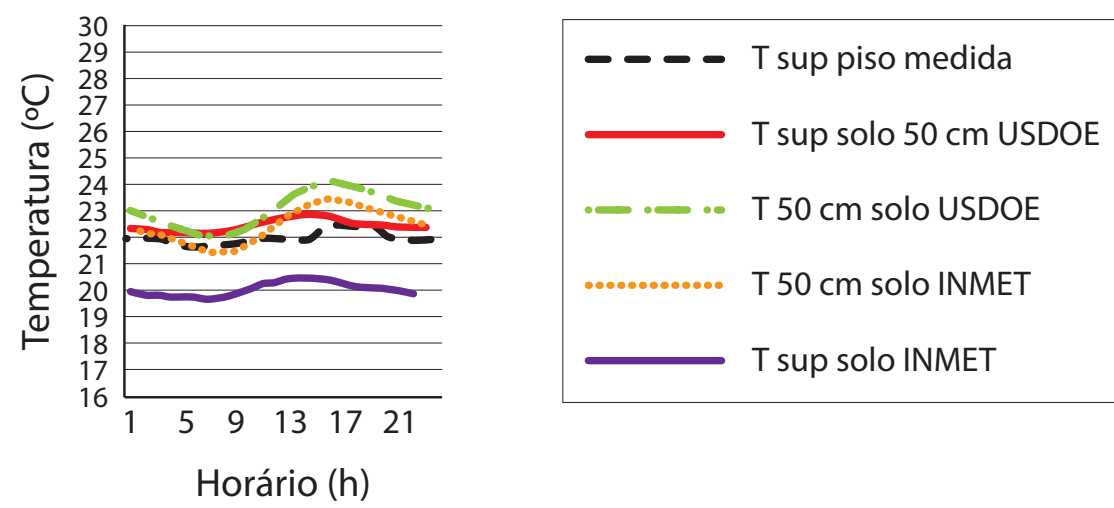

Figura 6. Temperatura do ar e do piso no dia 23/04.

Nas simulações para o dia 20 de julho (Figura 7), os resultados obtidos para a temperatura máxima e mínima do ar interior estão mais próximos dos valores medidos, com a temperatura superficial do solo de USDOE $\left(17,8^{\circ} \mathrm{C}\right)$. Nos demais casos, há uma diferença da ordem de $0,6^{\circ} \mathrm{C}$ entre valores medidos e calculados da temperatura máxima do ar interior e, da ordem de $1,5^{\circ} \mathrm{C}$ abaixo do valor mínimo medido. A temperatura superficial do piso interno difere dos dados medidos em até $2^{\circ} \mathrm{C}$, sendo os valores mais próximos dos medidos aqueles obtidos com a temperatura do solo de USDOE na superfície. 

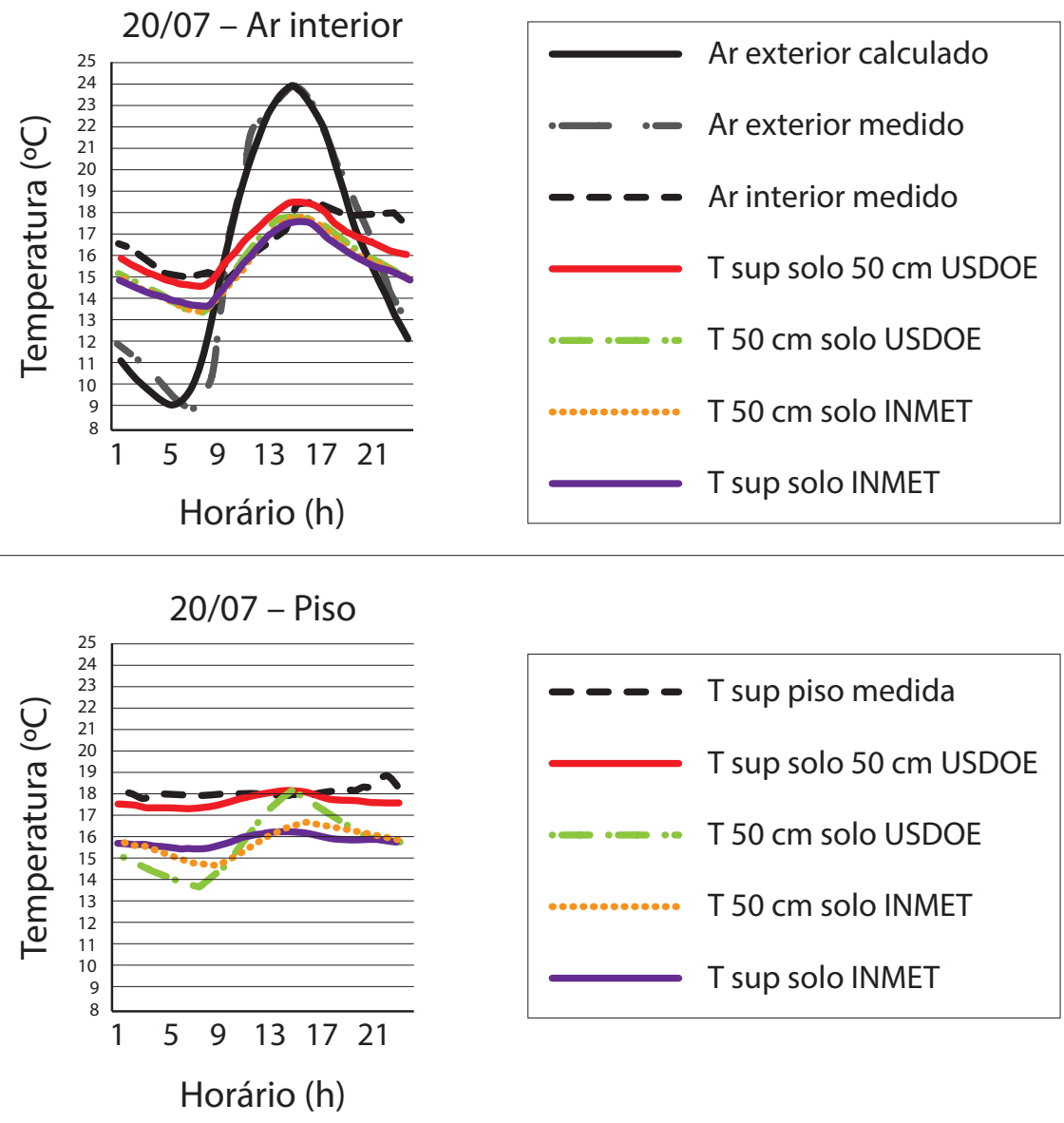

Figura 7. Temperatura do ar e do piso no dia 20/07.

Considerando-se que não foram feitos ajustes nos dados de entrada para que as temperaturas obtidas nas simulações fossem coincidentes com as obtidas nas mediçóes, os dados obtidos para os dias de abril e julho, com os vários valores da temperatura do solo e profundidades, seriam aceitáveis por propiciarem valores da temperatura do ar interior da mesma ordem de grandeza dos valores medidos.

\section{Conclusões}

Quanto ao efeito da temperatura do solo e sua profundidade, observou-se que uma variação de $2^{\circ} \mathrm{C}$ na temperatura do solo tem impacto pouco significativo na resposta térmica da edificação quando simulada em 
profundidade de $50 \mathrm{~cm}$. De modo geral, considerando-se que os dados de temperatura média mensal obtidos pelo INMET apresentam uma diferença de até $2^{\circ} \mathrm{C}$ em relação aos dados de temperatura do solo obtidos pelo USDOE, nos casos em que não há informações sobre essa grandeza, pode-se adotar valores da temperatura média mensal do ar para compor valores da temperatura do solo nessa profundidade, sem comprometer o resultado da avaliação do desempenho térmico da edificação.

Quanto aos valores da temperatura do solo, independentemente da forma de simular a temperatura do solo, seja na superfície ou em maior profundidade, os resultados obtidos são da mesma ordem de grandeza, condição que torna possível utilizar qualquer um deles nas avaliaçóes. Entretanto, considerando que, em maior profundidade, a temperatura do solo é pouco afetada pelas condições térmicas externas, simular a temperatura do solo em profundidade de $50 \mathrm{~cm}$ pode ser uma opção mais adequada.

\subsubsection{Valores Sugeridos da Temperatura do Solo}

Para compor dados de dias típicos de verão, para as cidades cujos dados climáticos foram abordados neste trabalho, selecionou-se a maior temperatura média mensal do ar (USDOE, 2015), escolhendo-se o valor da temperatura média do solo em profundidade de $50 \mathrm{~cm}$ no mês de referência. $\mathrm{O}$ mesmo procedimento foi feito para os dias típicos de inverno, considerando-se o menor valor da temperatura mínima mensal do ar. Para a realização das simulaçóes, foi selecionado um dia em meados do mês, que apresentava a maior temperatura média mensal do ar para o verão e mínima para o inverno (dia 15).

Na Tabela 2, são apresentados os valores de referência da temperatura média mensal do solo e os dias do ano ideais para a realização das simulações computacionais da resposta térmica de edificaçôes em dias típicos de verão e de inverno, constates na norma NBR 15575 (ABNT, 2013), especialmente, com o intuito de padronizar dados de entrada a serem inseridos em simulaçóes para a avaliaçáo do desempenho térmico potencial de sistemas construtivos.

Para outros tipos de simulaçóes, na ausência de dados de temperatura do solo, é possível utilizar valores da temperatura média mensal do ar obtidas no INMET, com o intuito de compor valores da temperatura do solo em profundidade de $50 \mathrm{~cm}$, seguindo o procedimento descrito no primeiro parágrafo deste item, a fim de escolher meses representativos de verão e inverno. 
Tabela 2. Dados sugeridos para a temperatura do solo em cidades brasileiras.

\begin{tabular}{|c|c|c|c|c|}
\hline \multirow[t]{2}{*}{ Cidade } & \multicolumn{2}{|c|}{ Dia típico de verão } & \multicolumn{2}{|c|}{ Dia típico de inverno } \\
\hline & Dia do ano & $\begin{array}{c}\text { Temp. média } \\
\text { mensal do solo - } \\
\text { prof. } 50 \mathrm{~cm}^{\mathrm{a}}\end{array}$ & Dia do ano & $\begin{array}{c}\text { Temp.média } \\
\text { mensal do solo - } \\
\text { prof. } 50 \mathrm{~cm}^{\mathrm{a}}\end{array}$ \\
\hline Belém & $15 /$ fev. & 25,7 & - & - \\
\hline Belo Horizonte & 15/fev. & 23,0 & 15/jul. & 20,0 \\
\hline Boa Vista & 15 /set. & 28,6 & - & - \\
\hline Brasília & 15/set. & 21,5 & 15/jul. & 19,0 \\
\hline Campo Grande & 15/jan. & 25,8 & - & - \\
\hline Curitiba & $15 /$ fev. & 20,8 & 15/jun. & 15,1 \\
\hline Florianópolis & 15/fev. & 24,1 & 15/jul. & 17,0 \\
\hline Fortaleza & 15/jan. & 27,3 & - & - \\
\hline Manaus & 15 /set. & 26,7 & - & - \\
\hline Porto Velho & 15/out. & 25,7 & - & - \\
\hline Recife & 15/mar. & 28,2 & - & - \\
\hline Rio de Janeiro & 15/fev. & 26,5 & - & - \\
\hline Salvador & 15/fev. & 24,5 & - & - \\
\hline São Paulo & $15 /$ fev. & 21,4 & 15/jul. & 17,8 \\
\hline
\end{tabular}

\subsection{Dias Típicos de Projeto das Zonas Bioclimáticas 2 e 5}

Foram determinados os dias típicos de projeto para as cidades de São Lourenço - MG e Vitória da Conquista - BA, pertencentes, respectivamente, às Zonas Bioclimáticas 2 e 5, cujas informaçóes de temperatura do ar, referentes ao período de 1981 a 2011, foram obtidas no INMET (2015). Os dados de radiação solar incidente no plano horizontal foram obtidos no CRESESP-CEPEL (2015). Essas cidades foram escolhidas em decorrência de disponibilidade de dados.

Foram determinados os meses de verão e de inverno designados como "mais quentes" e "mais frios", tendo como referência as médias das temperaturas máximas diárias e as médias das temperaturas mínimas diárias, conforme método apresentado por Akutsu e Vittorino (1991). Posteriormente foram estabelecidos os valores da temperatura máxima e mínima diárias, que caracterizam dias típicos de verão e de inverno nos locais analisados, com frequência de ocorrência da ordem de 10\% (AKUTSU; 
VITTORINO, 1991). Com base nesses valores e nos valores de umidade relativa correspondentes, foram obtidos os valores da temperatura de bulbo úmido. Quanto à temperatura do solo, como recentemente houve uma atualizaçáo de dados de cidades brasileiras nos arquivos climáticos do EnergyPlus, foi extraída desta fonte a informação para a cidade de Vitória da Conquista (USDOE, 2017). Para a cidade de São Lourenço, por sua vez, foram utilizados dados do INMET (2015) referentes à temperatura média mensal do ar, conforme procedimentos citados anteriormente (Tabela 3).

Tabela 3. Dados de dias típicos de verão propostos para cidades nas Zonas Bioclimáticas 2 e 5 .

\begin{tabular}{|c|c|c|c|c|}
\hline \multirow{3}{*}{$\begin{array}{c}\text { Zona Bioclimática } \\
\text { Cidade } \\
\text { Dia Típico }\end{array}$} & \multicolumn{2}{|c|}{2} & \multicolumn{2}{|c|}{5} \\
\hline & \multicolumn{2}{|c|}{ São Lourenço - MG } & \multicolumn{2}{|c|}{ Vitória da Conquista - BA } \\
\hline & Verão & Inverno & Verão & Inverno \\
\hline Temp. Máxima Diária $\left({ }^{\circ} \mathrm{C}\right)$ & 31,8 & 19,2 & 31,7 & 20,4 \\
\hline $\begin{array}{c}\text { Amplitude Diária da Temp. } \\
\text { do } \operatorname{Ar}\left({ }^{\circ} \mathrm{C}\right)\end{array}$ & 11,7 & 16,6 & 10,3 & 9,7 \\
\hline Temp. de Bulbo Úmido $\left({ }^{\circ} \mathrm{C}\right)$ & 21,6 & 14,0 & 21,0 & 15,1 \\
\hline $\begin{array}{c}\text { Radiação Solar Global - } \\
\text { Plano Horizontal }\left(\mathrm{Wh} / \mathrm{m}^{2}\right)\end{array}$ & 5307 & 3595 & 5030 & 4110 \\
\hline $\begin{array}{l}\text { Temp. Média Mensal do } \\
\text { Solo em Prof. de } 50 \mathrm{~cm}\end{array}$ & 23,4 & 16,2 & 21,9 & 20,5 \\
\hline Dia do Ano & 15/fev. & 15/jul. & 15/fev. & 15/jul. \\
\hline
\end{tabular}

\subsection{Dados Climáticos de Cidades para Avaliações no SiNAT}

Foi efetuada uma análise dos dados climáticos das cidades indicadas na norma NBR 15575 (ABNT, 2013), com o intuito de identificar razóes que possam justificar os diferentes comportamentos térmicos de edificaçôes iguais expostas às condiçôes climáticas de uma mesma zona. Também foram feitas simulaçôes computacionais da resposta térmica de apartamento com vários sistemas construtivos, localizados no último pavimento da edificação, em contato com a cobertura e afastados do solo, sem a contribuição da sua inércia térmica, representando ambientes com condiçôes térmicas mais críticas. São apresentados resultados somente para um tipo de sistema construtivo, com a intenção de ilustrar os fatores a serem abordados. 
O projeto do apartamento foi obtido no documento elaborado pela CDHU (CDHU, 1997), que determina paredes com $10 \mathrm{~cm}$ de concreto comum, lajes de piso e de cobertura com a mesma espessura e material e telhado com telhas cerâmicas. Foram simulados, a partir dos procedimentos oferecidos pela NBR 15575 (ABNT, 2013), com ambientes ventilados a uma taxa de 1 Ren/h e janelas sem sombreamento, voltadas para a direção oeste no verão e sul no inverno. Foram analisados os resultados obtidos para a sala por terem sido considerados os mais críticos, sendo determinantes do nível de desempenho térmico obtido pela edificação.

Nas Figuras 8 e 9, são indicados os intervalos de temperatura do ar externo e radiação solar global nos dias típicos de verão para cidades das Zonas Bioclimáticas 3, 6, 7 e 8, e dias típicos de inverno para cidades da Zona Bioclimática 3. Na Figura 10, são apresentados, respectivamente, os valores máximos diários da temperatura do ar interior, obtidos nos recintos expostos às condiçóes climáticas de cidades da Zona Bioclimática 8 e, os valores limites para atendimento ao nível "Mínimo" de desempenho térmico nos dias típicos de verão.

Na Figura 11, são apresentados os valores máximos da temperatura do ar interior nos ambientes em cidades das Zonas Bioclimáticas 3, 6 e 7, além dos valores mínimos diários da temperatura do ar interior em cidades da Zona Bioclimática 3, bem como os valores limites para atendimento ao nível "Mínimo" de desempenho térmico nos dias típicos de verão e de inverno.

A habitação atende o nível "Mínimo" de desempenho térmico em dias típicos de verão nas cidades de Belém, Vitória, Porto Velho, Manaus e Rio Branco, que possuem duas características marcantes: amplitude diária acima de $7^{\circ} \mathrm{C}$ (Belém, Porto Velho e Rio Branco) ou radiação solar global menor que $5 \mathrm{~kW} / \mathrm{m}^{2}$ (Vitória). Nas demais cidades, nas quais o dia típico de projeto é caracterizado por amplitude diária menor que $7^{\circ} \mathrm{C}$ e radiação maior que $5 \mathrm{~kW} / \mathrm{m}^{2}$, a habitação não atende o nível "Mínimo" de desempenho térmico. Isso mostra que há, pelo menos, dois grupos de cidades com características climáticas diferentes do ponto de vista do desempenho térmico de uma edificação, mas que constam na mesma Zona Bioclimática 8. É evidente que seria necessário analisar as condiçôes climáticas de mais cidades para possibilitar a delimitação de novas zonas. Entretanto, essas informaçôes permitem ao menos estabelecer referências para se avaliar o desempenho térmico na Zona Bioclimática 8 com maior precisão, reduzindo 
a possibilidade de aprovar um sistema construtivo que atende o nível "Mínimo" de desempenho térmico em toda a Zona Bioclimática 8, quando na realidade, isso não é válido para todas as cidades que fazem parte dela.

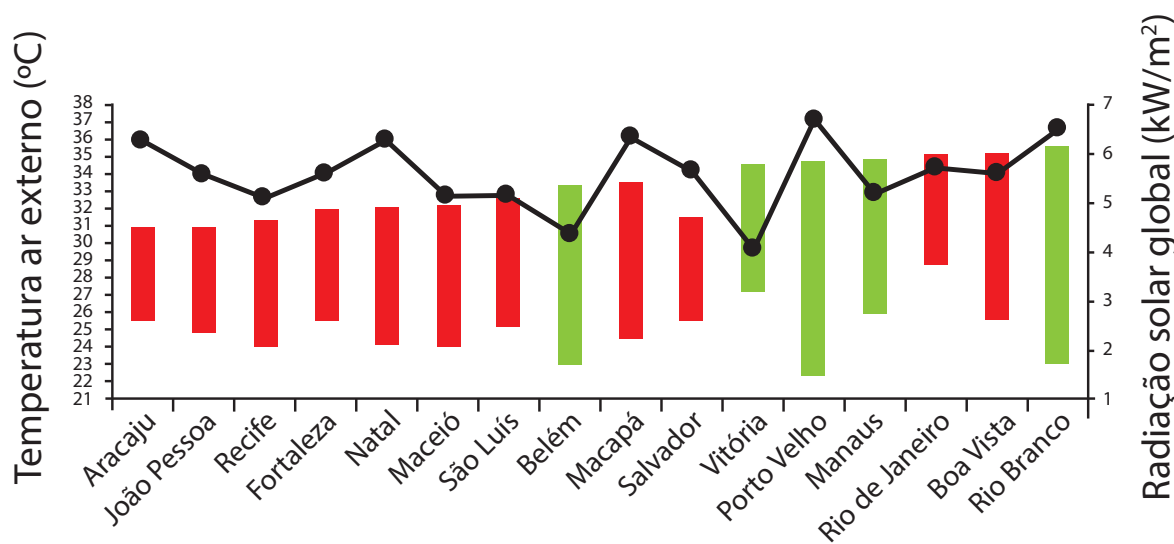

Z8

\section{$\rightarrow$ Radiação global - plano horizontal}

Figura 8. Temperatura do ar externo e radiação solar global incidente no plano horizontal para cidades da Zona Bioclimática 8, constantes na norma NBR 15575 (ABNT, 2013). Nota: Radiação solar global obtida no CRESESP-CEPEL para as cidades de Macapá e Boa Vista, pois não constam na norma NBR 15575 (ABNT, 2013).

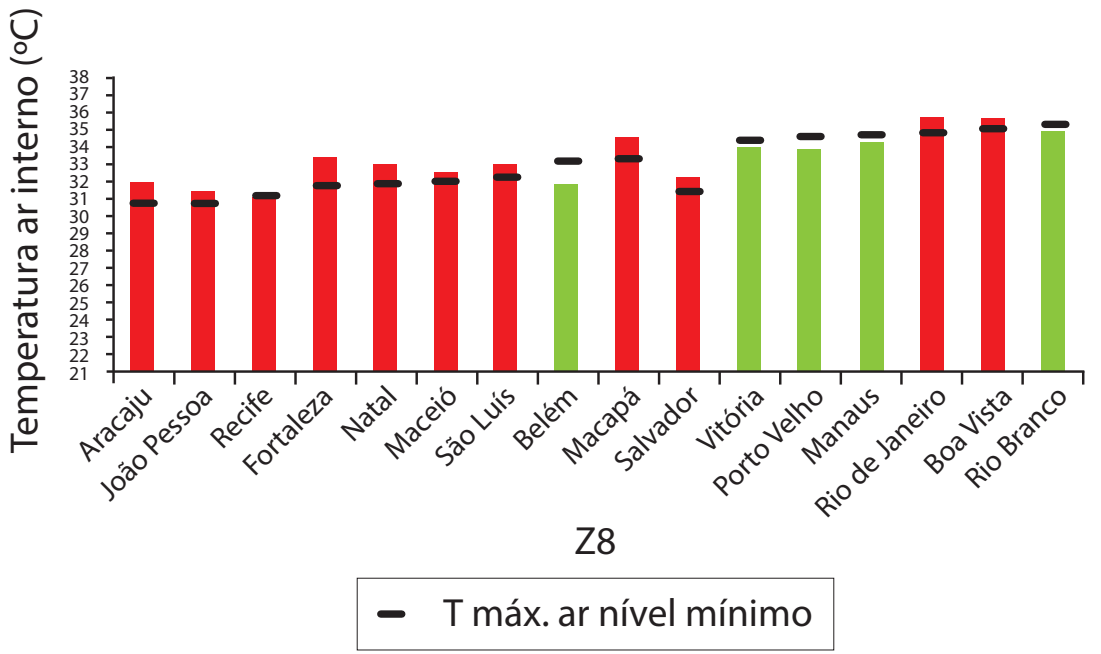

Figura 9. Temperatura máxima do ar interno obtidos na sala em apartamentos da Zona Bioclimática 8 e valor máximo da temperatura do ar para atender ao nível "Mínimo" de desempenho térmico. 

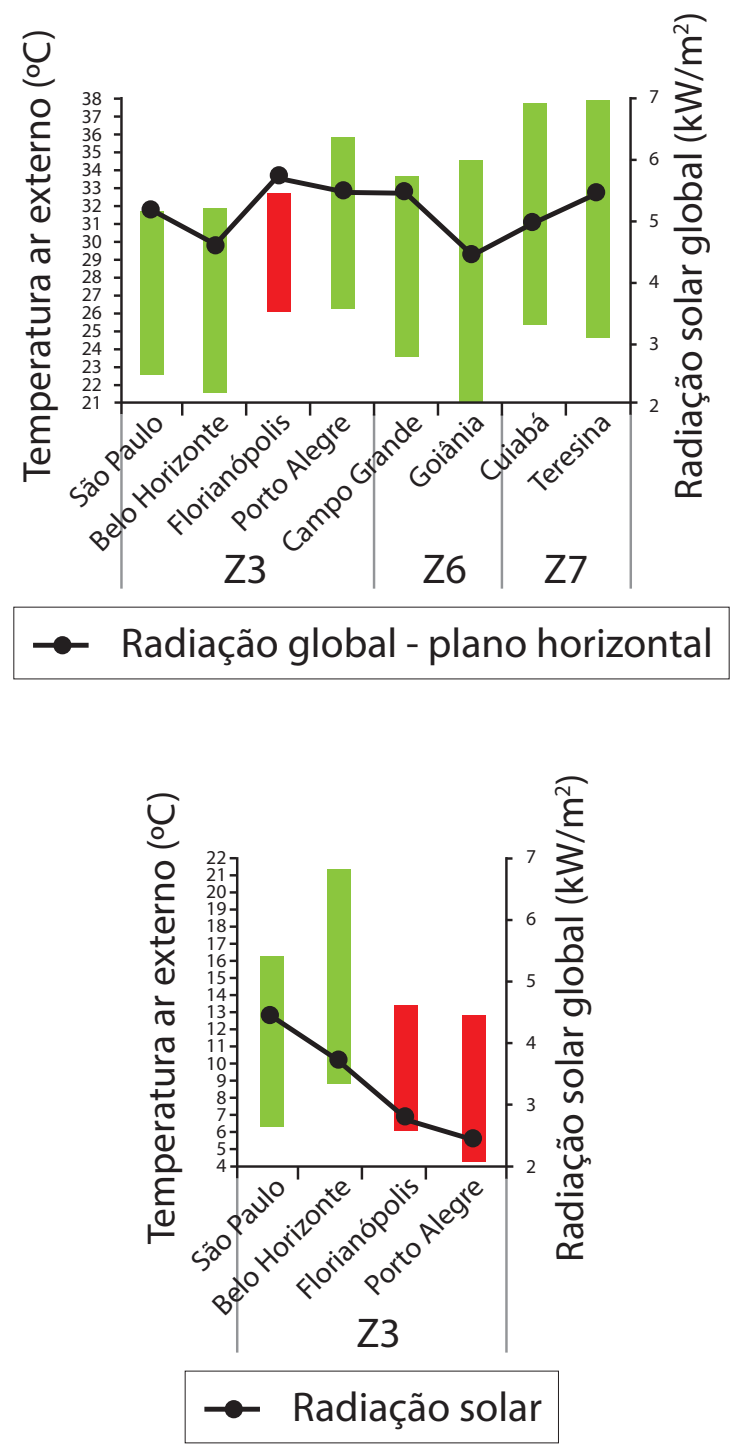

Figura 10. Temp. do ar externo e radiação solar global em cidades das Zonas 3, 6 e 7, constantes na norma NBR 15575 (ABNT, 2013) - dia típico de verão (à esquerda) e dia típico de inverno (à direita). Nota: Radiação solar global obtida no CRESESP-CEPEL para a cidade de Florianópolis, pois não consta na norma NBR 15575 (ABNT, 2013). 

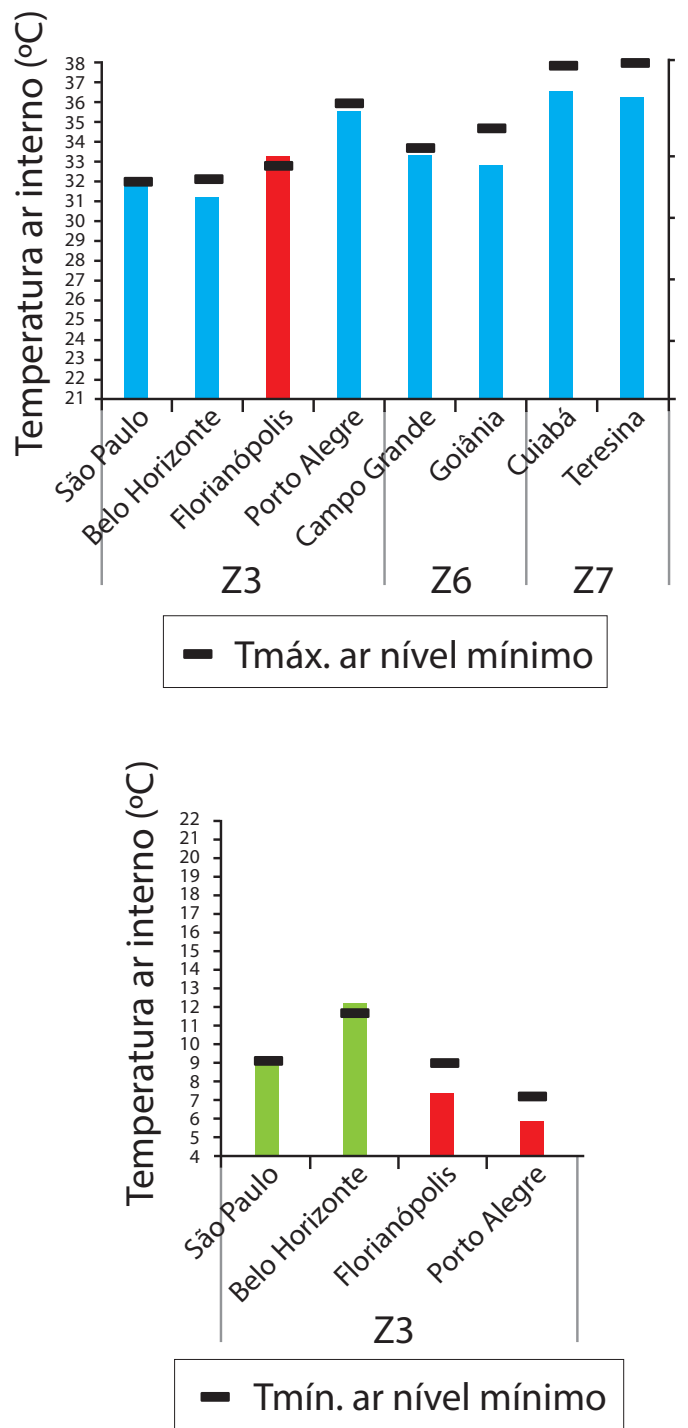

Figura 11. Temperatura máxima do ar interno obtidos na sala em apartamentos das Zonas Bioclimáticas 3, 6 e 7 (à esquerda) e Temperatura mínima do ar nos ambientes no inverno (à direita). 
Problemas semelhantes ocorrem nas cidades da Zona Bioclimática 3, em que a habitação avaliada não atende o nível "Mínimo" de desempenho térmico em Florianópolis (no verão e inverno) e em Porto Alegre (no inverno). Isso indica que nessa zona há cidades com três climas diferentes. São Paulo e Belo Horizonte tem dias típicos de verão semelhantes (amplitude diária da temperatura do ar e radiação solar da mesma ordem de grandeza), embora em São Paulo o inverno seja mais rigoroso. Florianópolis tem um dia típico de verão com menor amplitude diária que as outras cidades $\left(7,4^{\circ} \mathrm{C}\right)$, o que já caracteriza um clima diferente, com inverno rigoroso. Porto Alegre apresenta grande amplitude diária e temperaturas do ar significativamente maiores no verão e menores no inverno.

Os dias típicos nas cidades das Zonas Bioclimáticas 6 e 7 apresentam as mesmas características, embora não seja possível garantir que outras cidades nessas zonas apresentem clima semelhante a elas.

\subsubsection{Sugestões}

No intuito de contornar os problemas encontrados no zoneamento, reduzindo a possibilidade de aprovar um sistema construtivo que não tenha características adequadas ao clima do local, para a Zona Bioclimática 8, podem ser escolhidas duas cidades a fim de se realizar avaliaçóes no âmbito do SiNAT: uma com amplitude diária acima de $7^{\circ} \mathrm{C}$ ou radiação solar global menor que $5 \mathrm{~kW} / \mathrm{m}^{2}$ (Belém, Vitória, Porto Velho, Manaus, Rio Branco) e outra com amplitude diária menor que $7^{\circ} \mathrm{C}$ e radiação maior que $5 \mathrm{~kW} / \mathrm{m}^{2}$ (Aracaju, João Pessoa, Recife, Fortaleza, Natal, Maceió, São Luís, Macapá, Salvador, Rio de Janeiro, Boa Vista). A aprovação do sistema construtivo nas duas cidades indica maior probabilidade de atendimento ao nível "Mínimo" nas demais da Zona Bioclimática 8. Quanto à Zona Bioclimática 3, de modo análogo, poderiam ser adotadas duas cidades: com amplitude diária em dias típicos de projeto maior que $7^{\circ} \mathrm{C}$ (São Paulo, Belo Horizonte e Porto Alegre) e menor ou igual a $7^{\circ} \mathrm{C}$ (Florianópolis).

Outra possibilidade seria adotar um novo zoneamento, como o que é apresentado por Akutsu (1998), que leva em conta as temperaturas máximas e mínimas mensais e a amplitude anual da temperatura do ar. Embora esse zoneamento seja mais adequado que o apresentado na norma NBR 15220 
(ABNT, 2008) para fazer avaliaçóes do desempenho térmico de edificaçóes, precisaria ser atualizado e complementado com a inclusão de informaçóes sobre radiação solar.

\subsection{Outras Variáveis de Simulação}

Foram efetuadas discussóes com a Instituição de Avaliação Técnica Falcão Bauer e com a Caixa Econômica Federal, visando à padronização de dados climáticos para a realização de simulaçôes no âmbito do SiNAT. Com a Caixa, especificamente, foram desenvolvidos projetos de referência para as simulaçôes, baseados nas dimensôes típicas das habitaçôes financiadas por esse órgão, bem como nas exigências de tamanhos de aberturas, além da padronização de aspectos inerentes ao sistema construtivo, como cores das superfícies externas de telhados e conteúdo mínimo de um relatório de avaliação de desempenho térmico.

\section{Proposta de Procedimentos para Avaliar o Desempenho Térmico Potencial de um Sistema Construtivo}

$\mathrm{Na}$ avaliação do desempenho térmico de edificações não climatizadas pelo método detalhado, conforme a norma NBR 15575 (ABNT, 2013), inicialmente deve-se selecionar a opção mais adequada ao objetivo da avaliaçáo, como indicado nos itens a seguir:

a) Identificar o desempenho térmico de uma edificação específica a ser construída em determinado terreno;

b) Identificar o desempenho térmico potencial de um sistema construtivo.

Para avaliar uma edificação específica, como descrito no objetivo (a), podem ser abordadas todas as circunstâncias particulares da edificação, tais como: exposição ao microclima do local, forma e parâmetros físicos e térmicos da envoltória, sua implantação, orientação solar das fachadas, condiçôes de ventilação dos ambientes, dentre outras. A edificação pode ser analisada por simulaçôes computacionais ou mediçôes.

Nas simulaçôes, pode ser utilizado tanto o modelo simplificado de ventilação natural ou modelos complexos que indiquem a eficiência 
da ventilação em função dos fatores geométricos da edificação, quanto a posição de aberturas e disposição de paredes. Nas mediçóes, é necessário ter maiores cuidados para verificar qual é o rigor da avaliação, comparando as características do dia medido com os dias típicos de projeto (temperatura do ar externo, umidade relativa, velocidade do vento, radiação solar, incidente global, incidente no plano horizontal), além de analisar dados do terceiro dia de uma sequência de três dias. Os resultados da avaliação são aplicáveis exclusivamente à edificação avaliada, no local considerado, não podendo ser generalizados.

Para identificar o desempenho térmico potencial de um sistema construtivo, deve ser utilizado o método detalhado por simulaçóes computacionais previsto na norma NBR 15575 (ABNT, 2013), além dos procedimentos complementares indicados no item 2.1.

\subsection{Simulações}

Os procedimentos padronizados de ensaio incluem: condiçóes climáticas de cidades representativas de cada Zona Bioclimática Brasileira; orientação solar das fachadas de dormitórios e salas; cores das superfícies externas das paredes e da cobertura; condiçóes de ocupação e de ventilação dos ambientes, além da geometria da edificação (projetos padrão de ensaio).

É necessário que seja utilizado um programa de simulação computacional que apresente a resposta térmica de edificaçóes considerando condiçôes transientes de trocas térmicas, levando em consideração o efeito da inércia térmica. O programa EnergyPlus é reconhecido por fazer tais simulações, é de domínio público, sugerindo-se sua adoção para efetuar as simulaçóes.

\subsubsection{Condições Climáticas}

Devem ser consideradas as condiçóes climáticas para os dias típicos de projeto no verão e no inverno em cidades representativas das Zonas Bioclimáticas Brasileiras, de acordo com a Tabela 4. Deve-se adotar direção do vento perpendicular à fachada do ambiente analisado e velocidade do vento de $1 \mathrm{~m} / \mathrm{s}$ como padrão para todas as cidades representativas das Zonas Bioclimáticas. 
Tabela 4. Dados de dias típicos de verão e inverno.

\begin{tabular}{|c|c|c|c|c|c|c|c|c|c|}
\hline 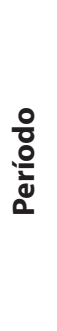 & $\begin{array}{l}\text { Zona } \\
\text { Biocl. }\end{array}$ & Cidade & UF & $\begin{array}{c}\text { Dia } \\
\text { do } \\
\text { ano }\end{array}$ & $\begin{array}{l}\text { Temp. } \\
\text { do } \\
\text { solo - } \\
\text { prof. } \\
50 \mathrm{~cm} \\
\left({ }^{\circ} \mathrm{C}\right)\end{array}$ & $\begin{array}{l}\text { Temp. } \\
\text { Máx. } \\
\text { Bulbo } \\
\text { Seco } \\
\left({ }^{\circ} \mathrm{C}\right)\end{array}$ & $\begin{array}{l}\text { Amplitude } \\
\text { diária da } \\
\text { temp. do } \\
\text { ar } \\
\left({ }^{\circ} \mathrm{C}\right)\end{array}$ & $\begin{array}{c}\text { Temp. } \\
\text { Bulbo } \\
\text { Úmido } \\
\text { (TBS } \\
\text { Máx.) } \\
\left({ }^{\circ} \mathrm{C}\right)\end{array}$ & $\begin{array}{c}\text { Radiação } \\
\text { solar } \\
\text { global } \\
\text { incidente } \\
\text { no plano } \\
\text { horizontal } \\
\left(\mathrm{kW} / \mathrm{m}^{2}\right)\end{array}$ \\
\hline \multirow{10}{*}{$\frac{\sqrt[2]{\pi}}{\stackrel{2 \pi}{\infty}}$} & 1 & Curitiba & PR & $\begin{array}{l}15 / \\
\text { fev. }\end{array}$ & 20,8 & 31,4 & 10,2 & 21,3 & 2,77 \\
\hline & 2 & $\begin{array}{c}\text { São } \\
\text { Lourenço }\end{array}$ & MG & $\begin{array}{l}15 / \\
\text { fev. }\end{array}$ & 23,4 & 31,8 & 11,7 & 21,6 & 5,30 \\
\hline & \multirow{2}{*}{3} & São Paulo & $\mathrm{SP}$ & $\begin{array}{l}15 / \\
\text { fev. }\end{array}$ & 21,4 & 31,9 & 9,2 & 21,3 & 5,18 \\
\hline & & Florianópolis & SC & $\begin{array}{l}15 / \\
\text { fev. }\end{array}$ & 24,1 & 32,7 & 6,6 & 24,4 & $5,73^{a}$ \\
\hline & 4 & Brasília & DF & $\begin{array}{l}15 / \\
\text { set. }\end{array}$ & 21,5 & 31,2 & 12,5 & 20,9 & 4,62 \\
\hline & 5 & $\begin{array}{l}\text { Vitória da } \\
\text { Conquista }\end{array}$ & BA & $\begin{array}{l}15 / \\
\text { fev. }\end{array}$ & 21,9 & 31,7 & 10,3 & 21,0 & 5,03 \\
\hline & 6 & Cuiabá & MT & $\begin{array}{l}15 / \\
\text { out. }\end{array}$ & 25,7 & 37,8 & 12,4 & 24,8 & 4,97 \\
\hline & 7 & $\begin{array}{l}\text { Campo } \\
\text { Grande }\end{array}$ & MG & $\begin{array}{l}15 / \\
\text { jan. }\end{array}$ & 25,8 & 33,6 & 10 & 23,6 & 5,48 \\
\hline & 8 & Manaus & $\mathrm{AM}$ & $\begin{array}{l}15 / \\
\text { set. }\end{array}$ & 26,7 & 34,9 & 9,1 & 26,4 & 5,18 \\
\hline & 0 & Recife & PE & $\begin{array}{l}15 / \\
\text { mar. }\end{array}$ & 28,2 & 31,4 & 7,4 & 24,7 & 5,10 \\
\hline \multirow{6}{*}{ 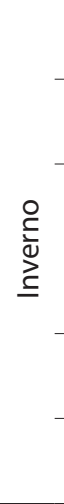 } & 1 & Curitiba & PR & $\begin{array}{l}15 / \\
\text { jun. }\end{array}$ & 15,1 & 12,3 & 11,6 & 11 & 1,66 \\
\hline & 2 & $\begin{array}{c}\text { São } \\
\text { Lourenço }\end{array}$ & MG & $\begin{array}{l}15 / \\
\text { jul. }\end{array}$ & 16,2 & 19,2 & 16,6 & 14,0 & 3,59 \\
\hline & & São Paulo & $\mathrm{SP}$ & $\begin{array}{l}\text { 15/ } \\
\text { jul. }\end{array}$ & 17,8 & 16,2 & 10 & 13,4 & 4,42 \\
\hline & 3 & Florianópolis & SC & $\begin{array}{l}\text { 15/ } \\
\text { jul. }\end{array}$ & 17,0 & 13,4 & 7,4 & 13,4 & $2,74^{\mathrm{a}}$ \\
\hline & 4 & Brasília & DF & $\begin{array}{l}\text { 15/ } \\
\text { jul. }\end{array}$ & 19,0 & 22,2 & 12,2 & 14,8 & 4,25 \\
\hline & 5 & $\begin{array}{l}\text { Vitória da } \\
\text { Conquista }\end{array}$ & $\mathrm{BA}$ & $\begin{array}{l}\text { 15/ } \\
\text { jul. }\end{array}$ & 20,5 & 20,4 & 9,7 & 15,1 & 4,11 \\
\hline
\end{tabular}

a Radiação solar global de Florianópolis obtida no CRESESP-CEPEL, pois não consta na norma NBR 15575 (ABNT, 2013).

${ }^{\mathrm{b}}$ Temperatura do solo para ser simulada em profundidade de $50 \mathrm{~cm}$. Características do solo: condutividade térmica de 0,6 W/(m.K), massa específica de $1700 \mathrm{~kg} / \mathrm{m}^{3}$ e calor específico de $840 \mathrm{~J} /(\mathrm{kg} . \mathrm{K})$. 
Observa-se que os resultados das avaliações do desempenho térmico de edificações nas cidades indicadas nas referidas tabelas podem ser estendidos a outras cidades, desde que alocadas na mesma Zona Bioclimática considerada na avaliação. Para as zonas bioclimáticas que têm duas cidades indicadas, a edificação deve atender ao nível "Mínimo" em ambas para que os resultados sejam estendidos às outras cidades da Zona. Caso isso não ocorra, os resultados serão válidos somente para a cidade na qual o sistema construtivo foi aprovado. Caso sejam utilizados dados geográficos e climáticos diferentes dos apresentados nas referidas tabelas, os resultados da avaliação não serão aceitos.

\subsubsection{Projeto Padrão de Ensaio}

Devem ser considerados os projetos padrão de ensaio indicados no Anexo, que incluem casa térrea isolada e geminada, casa sobreposta e apartamento. Caso seja necessário avaliar um sobrado, pode ser analisada a casa térrea geminada, simulada com o piso em contato com outra edificação idêntica em vez de estar em contato com o solo.

\subsubsection{Simulações dos Ambientes}

O projeto da unidade habitacional deve ser simulado por completo, com cada ambiente representando uma zona térmica. Adotar a situação mais crítica de exposição à radiação solar, como disposto a seguir:

a) Apartamento ou ambiente localizado no último pavimento, com sala e dormitório em contato com a cobertura da edificação;

b) Ambiente sala e ambiente dormitório com maior área envidraçada na fachada, com janela voltada para a direçáo oeste e uma parede para norte, no período de verão. No período de inverno, a janela deve ser voltada para a direção sul e uma parede para leste;

c) Ambiente sala e ambiente dormitório com o maior número de paredes expostas ao clima, tanto no veráo quanto no inverno.

d) As simulações são realizadas para os dois ambientes, sala e dormitório, posicionados individualmente na situação mais crítica. Isso significa que deve ser feita uma primeira simulação, posicionando-se a sala na situação mais crítica, e uma segunda simulação, posicionando-se o dormitório na situaçáo mais crítica. Em ambas as situaçóes, são obtidos os resultados para todos os ambientes, adotando-se, para efeito da análise, os resultados mais desfavoráveis. 


\subsubsection{Absortância à Radiação Solar de Superfícies}

Considerar superfícies externas das fachadas em cores claras, médias e escuras, com absortância à radiação solar de 0,3,0,5 e 0,7, respectivamente, e superfícies externas das telhas do telhado, conforme indicado na Tabela 5.

Tabela 5. Absortância à radiação solar de superfícies externas de telhados ou coberturas.

\begin{tabular}{cc}
\hline Tipo de cobertura ou cor & $\begin{array}{c}\text { Absortância da superfície externa } \\
\text { da cobertura }\end{array}$ \\
\hline Cerâmica & 0,7 \\
\hline Fibrocimento & 0,7 \\
\hline Concreto & 0,7 \\
\hline Cobertura em cor clara, com absortância de 0,3 & 0,5 \\
\hline Cobertura em cor média, com absortância de 0,5 & 0,7 \\
\hline Cobertura em cor escura, com absortância de 0,7 & 0,9 \\
\hline $\begin{array}{l}\text { É obrigatória a apresentação de resultados de simulações considerando as absortâncias das superfí- } \\
\text { cies da cobertura previstas nesta tabela, que representam condições que poderão ser encontradas em } \\
\text { coberturas "envelhecidas". }\end{array}$
\end{tabular}

\subsection{5. Ático}

As simulaçôes devem ser realizadas considerando ático "não ventilado", com as dimensôes previstas nos projetos padrão. Caso o sistema construtivo da cobertura necessite de uma inclinação diferente daquelas indicadas nos projetos, essa informaçáo deve ser destacada no relatório da avaliação, incluindo as dimensôes utilizadas.

\subsubsection{Pé-direito}

Utilizar o pé-direito indicado nos projetos padrão. Caso o sistema construtivo não contemple forro, adotar a inclinação do telhado do projeto padrão. Para coberturas sem forro e com inclinação diferente da prevista no projeto padrão, essa informação deve ser destacada no relatório da avaliação, incluindo as dimensões utilizadas. 


\subsubsection{Ocupação}

Os recintos devem ser simulados sem a presença de pessoas, equipamentos e iluminação, de modo a se obter informaçôes somente da resposta térmica da edificação, decorrente da sua interação com o clima do local.

\subsubsection{Sombreamento de Janelas e Ventilação de Ambientes}

Os recintos devem ser simulados considerando as quatro situaçóes apresentadas abaixo para o período de verão e a situação apresentada para o período de inverno. Devem ser utilizados os modelos de ventilação simplificados que permitem a inclusão do número de renovaçóes do ar nos ambientes, padronizado pela norma NBR 15575 (ABNT, 2013). Ressalta-se a importância desse fator para padronização do ensaio, pois tais modelos não levam em conta especificidades da geometria.

\section{Período de Verão}

a) Ambiente com ventilação a uma taxa de 1,0 Ren/h (uma renovação do volume de ar do ambiente por hora), durante as 24 horas do dia, com janelas sem sombreamento. Considerar a área total da janela como envidraçada, ou seja, sem sombreamento. Essa condição de simulação é denominada como condição padrão, "PADRÃO";

b) Janelas sombreadas, ou seja, com proteçáo solar, como cortinas ou outros elementos, que impeçam a entrada de radiação solar direta ou reduzam em $50 \%$ a incidência da radiação solar global no ambiente. Considerar o ambiente com ventilação a uma taxa de 1,0 Ren/h (uma renovação do volume de ar do ambiente por hora), durante as 24 horas do dia. Essa condição de simulaçấo é denominada como condição com sombreamento, "SOMB";

c) Ambiente ventilado a uma taxa de 5,0 Ren/h (cinco renovaçóes do volume de ar do ambiente por hora), durante as 24 horas do dia. Considerar a janela com sua área total envidraçada, ou seja, sem sombreamento. Essa condição de simulação é denominada como condição com ventilação, "VENT";

d) Simulação com a combinação das duas opçôes anteriormente expostas em "b" e "c", ou seja, condição com sombreamento e ventilação, denominada como "SOMB + VENT". Considerar, portanto, ambiente ventilado a uma taxa de 5,0 Ren/h e janelas sombreadas, ou seja, com proteçâo solar que impeça a entrada de radiação solar direta ou reduzam em $50 \%$ a incidência da radiaçấo solar global no ambiente. 


\section{Período de Inverno}

Ambiente com ventilação a uma taxa de 1,0 Ren/h (uma renovação do volume de ar do ambiente por hora), durante as 24 horas do dia, com janelas sem sombreamento, ou seja, considerar a janela com sua área total envidraçada. Essa condição de simulação é denominada como condição padrão, "PADRÃO".

\subsubsection{Análise dos Resultados}

Analisar a resposta térmica tanto de salas como de dormitórios, ou seja, dos ambientes de ocupação prolongada, que apresentem condições mais críticas de exposição à radiação solar no período considerado.

Para que se considere que a habitação atende aos critérios referentes ao nível mínimo de desempenho térmico previsto na norma NBR 15575 (ABNT, 2013), é necessário que salas e dormitórios atendam o nível mínimo de desempenho térmico no verão e no inverno, como disposto a seguir:

a) Atendimento ao nível de desempenho térmico mínimo no verão: o nível mínimo (M) é atendido quando o valor máximo diário da temperatura do ar interior é menor ou igual ao valor máximo diário da temperatura do ar exterior;

b) Atendimento ao nível de desempenho térmico mínimo no inverno: o nível mínimo (M) é atendido quando o valor mínimo diário da temperatura do ar interior é maior ou igual ao valor mínimo diário da temperatura do ar exterior acrescido de $3^{\circ} \mathrm{C}$.

c) Para informações sobre os critérios referentes aos outros níveis de desempenho térmico, consultar o Anexo E da parte 1 da norma NBR 15575 (ABNT, 2013).

\subsubsection{Informações Básicas do Relatório da Avaliação}

a) Projeto arquitetônico da edificação, incluindo plantas, cortes e vistas. Os cortes devem apresentar seçóes do ático, se houver;

b) Descrição do sistema construtivo e da edificação considerada (paredes, cobertura, pisos, janelas, portas), destacando detalhes das paredes, de seus componentes e revestimentos, cor da cobertura, pé-direito, área envidraçada na fachada em relação à área de piso dos ambientes (Tabela 6);

c) Detalhamento do sistema construtivo, disposição e espessuras de camadas; 
d) Propriedades térmicas e físicas dos materiais que compóem o sistema construtivo, como condutividade térmica, calor específico, massa específica e emissividade das superfícies;

e) Descrição do método utilizado na avaliação (ABNT, 2013);

f) Apresentação de tabelas com os resultados do atendimento a critérios referentes aos níveis de desempenho térmico da habitação no período de verão e no período de inverno (Tabelas 7 e 8). Deve haver uma legenda com a indicação das cores que representam os níveis de desempenho térmico;

g) Indicação do resultado final da avaliação em uma tabela contendo o resumo de todas as condiçóes que proporcionam o atendimento aos níveis de desempenho, como indicado no exemplo da Tabela 9;

h) Conclusão com a indicação clara do atendimento ou não a critérios referentes aos níveis de desempenho térmico constantes na norma. Assinatura de um responsável técnico.

Tabela 6. Área envidraçada na fachada dos ambientes por tipologia.

\begin{tabular}{ccccc}
\hline Ambiente & Casa Térrea & $\begin{array}{c}\text { Casa térrea } \\
\text { geminada }\end{array}$ & $\begin{array}{c}\text { Casa } \\
\text { sobreposta }\end{array}$ & Apartamento \\
\hline Dorm. Casal & $15 \%$ & $20 \%$ & $15 \%$ & $15 \%$ \\
\hline Dorm. Solt. & $18 \%$ & $28 \%$ & $18 \%$ & $18 \%$ \\
\hline Sala e Coz. & $22 \%$ & $21 \%$ & $22 \%$ & $18 \%$ \\
\hline
\end{tabular}

Tabela 7. Resultados da avaliação do desempenho térmico da edificação no verão.

\begin{tabular}{|c|c|c|c|c|c|c|c|c|c|c|}
\hline \multirow[b]{2}{*}{$\begin{array}{c}\text { Zona } \\
\text { Bioclimática }\end{array}$} & \multirow{2}{*}{$\begin{array}{c}\text { Temp. } \\
\text { máx. } \\
\text { ar } \\
\text { ext. }\end{array}$} & \multirow{2}{*}{$\begin{array}{c}\text { Cor da } \\
\text { parede } \\
\text { ext. }\end{array}$} & \multicolumn{4}{|c|}{ Dormitório/Condição } & \multicolumn{4}{|c|}{ Sala/Condição } \\
\hline & & & ㄴ & ํํํ & 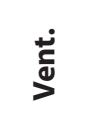 & $\begin{array}{l}\stackrel{0}{0} \\
\dot{c} \\
\stackrel{0}{0} \\
\dot{0}\end{array}$ & ษิ & ह̊ & 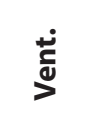 & 을 \\
\hline \multirow{3}{*}{$\mathrm{X}$} & \multirow{3}{*}{ Valor } & Clara & valor & valor & valor & valor & valor & valor & valor & valor \\
\hline & & Média & valor & valor & valor & valor & valor & valor & valor & valor \\
\hline & & Escura & valor & valor & valor & valor & valor & valor & valor & valor \\
\hline \multirow{3}{*}{-} & \multirow{3}{*}{ Valor } & Clara & valor & valor & valor & valor & valor & valor & valor & valor \\
\hline & & Média & valor & valor & valor & valor & valor & valor & valor & valor \\
\hline & & Escura & valor & valor & valor & valor & valor & valor & valor & valor \\
\hline
\end{tabular}


Tabela 8. Resultados da avaliação do desempenho térmico da edificação no inverno.

\begin{tabular}{|c|c|c|c|c|}
\hline $70 m a$ & & Cordamarods & Dormitório/condição & Sala/condição \\
\hline Bioclimática & ext. & ext. & CP & CP \\
\hline \multirow{3}{*}{1} & \multirow{3}{*}{ Valor } & Clara & valor & valor \\
\hline & & Média & valor & valor \\
\hline & & Escura & valor & valor \\
\hline \multirow{3}{*}{-} & \multirow{3}{*}{ Valor } & Clara & valor & valor \\
\hline & & Média & valor & valor \\
\hline & & Escura & valor & valor \\
\hline \multicolumn{5}{|c|}{$\begin{array}{l}\text { - nível de desempenho térmico abaixo do "Mínimo"; } \\
\text { - nível de desempenho térmico "Mínimo"; } \\
\text { - nível de desempenho térmico "Intermediário"; } \\
\text { - nível de desempenho térmico "Superior". }\end{array}$} \\
\hline
\end{tabular}

Tabela 9. Resumo dos resultados da avaliação do desempenho térmico da edificação com indicação do atendimento ao nível "Mínimo" de desempenho.

\begin{tabular}{ccccc}
\hline \multirow{2}{*}{$\begin{array}{c}\text { Zona } \\
\text { Bioclimática }\end{array}$} & $\begin{array}{c}\text { Condição } \\
\text { padrão }\end{array}$ & $\begin{array}{c}\text { Com } \\
\text { sombreamento }\end{array}$ & $\begin{array}{c}\text { Com } \\
\text { ventilação }\end{array}$ & $\begin{array}{c}\text { Com } \\
\text { sombreamento } \\
\text { e ventilação }\end{array}$ \\
\cline { 2 - 5 } & $\begin{array}{c}\text { Atende com cor } \\
\text { clara ou média }\end{array}$ & $\begin{array}{c}\text { Atende com cor } \\
\text { clara ou média }\end{array}$ & $\begin{array}{c}\text { Atende com cor } \\
\text { clara ou média }\end{array}$ & $\begin{array}{c}\text { Atende com } \\
\text { qualquer cor }\end{array}$ \\
\hline $\mathbf{1}$ & $\begin{array}{c}\text { Atende com } \\
\text { qualquer cor }\end{array}$ & $\begin{array}{c}\text { Atende com } \\
\text { qualquer cor }\end{array}$ & $\begin{array}{c}\text { Atende com } \\
\text { qualquer cor }\end{array}$ & $\begin{array}{c}\text { Atende com } \\
\text { qualquer cor }\end{array}$ \\
\hline
\end{tabular}

\subsubsection{Informações Básicas do DATec}

O DATec deve reunir as tabelas com o resultado das condiçóes em que a habitação atende, pelo menos, o nível "Mínimo", além de disponibilizar uma descrição sucinta da tipologia e características da habitação avaliada, incluindo a cor da cobertura, altura do ático, se houver, pé-direito, área envidraçada na fachada em relação à área de piso dos ambientes. A avaliação será válida somente para edificaçôes com as características descritas no DATec. Caso o construtor necessite fazer uma habitação com um projeto com maior área envidraçada na fachada ou cor mais escura na cobertura, por exemplo, será necessário fazer uma nova avaliação do projeto específico. 


\section{Anexos - Projetos padrão de ensaio}

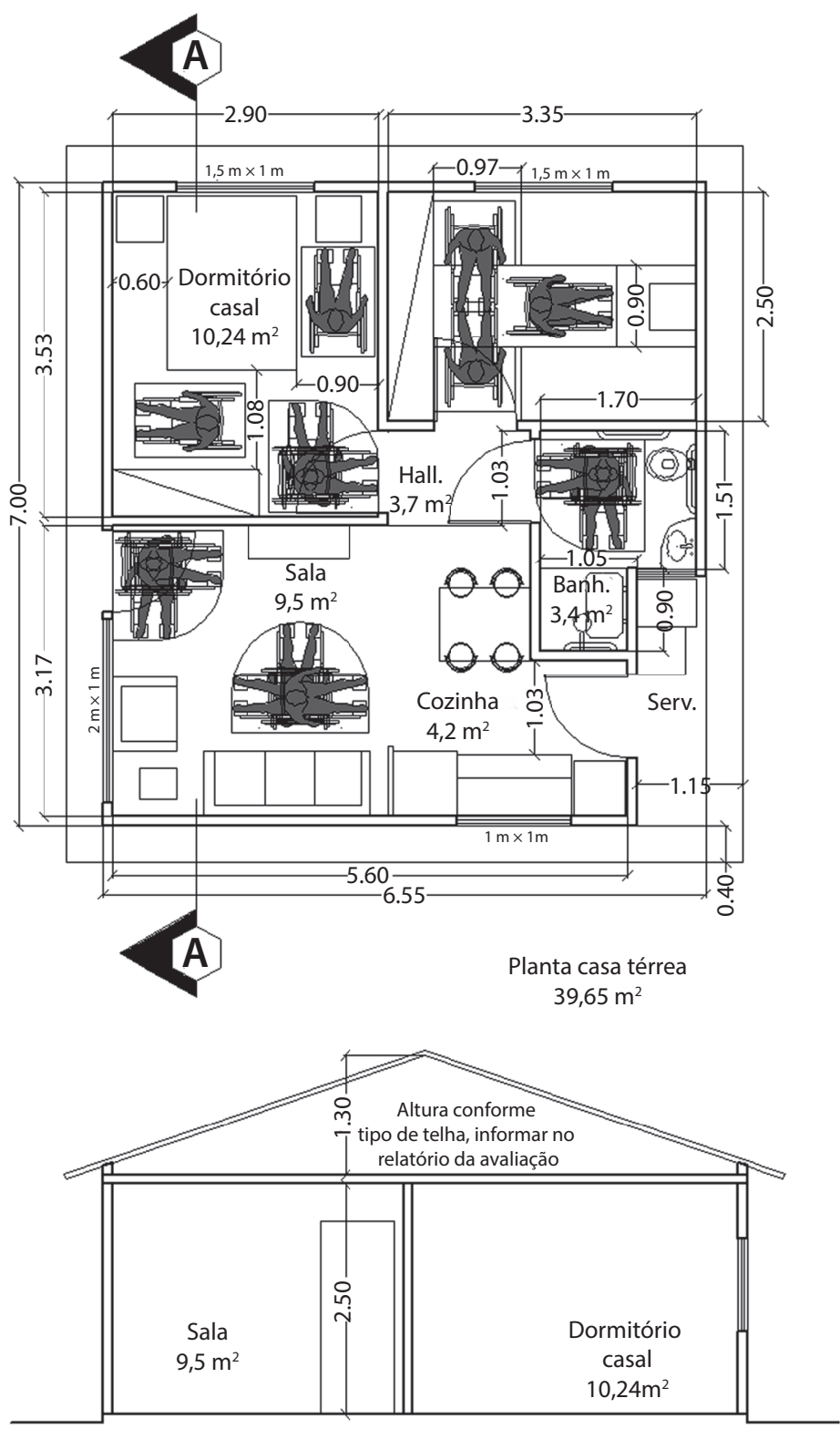

Corte casa térrea

isolada

$39,65 \mathrm{~m}^{2}$

Figura A1. Projeto de casa térrea. 


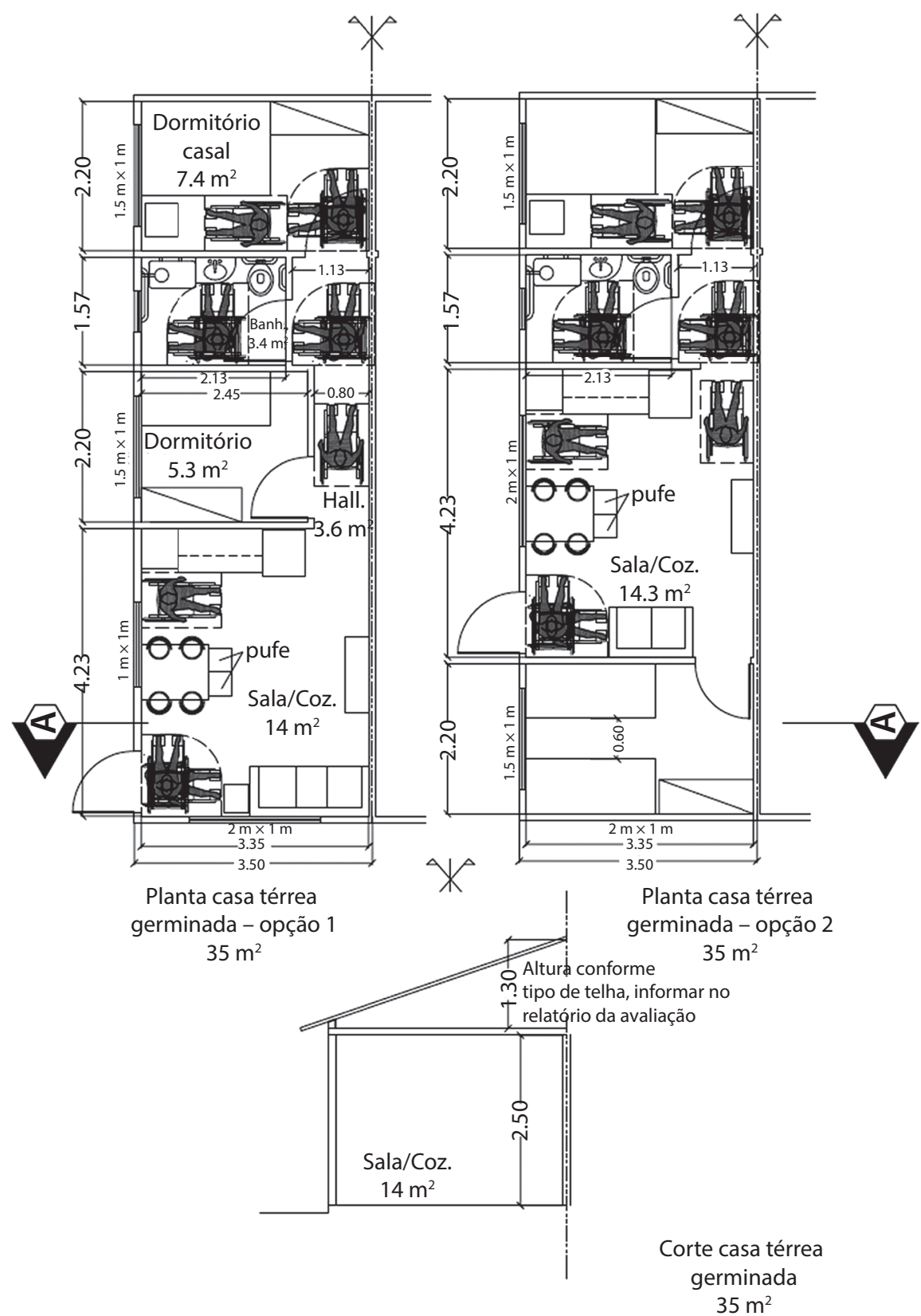

Figura A2. Projeto de casa térrea geminada. 

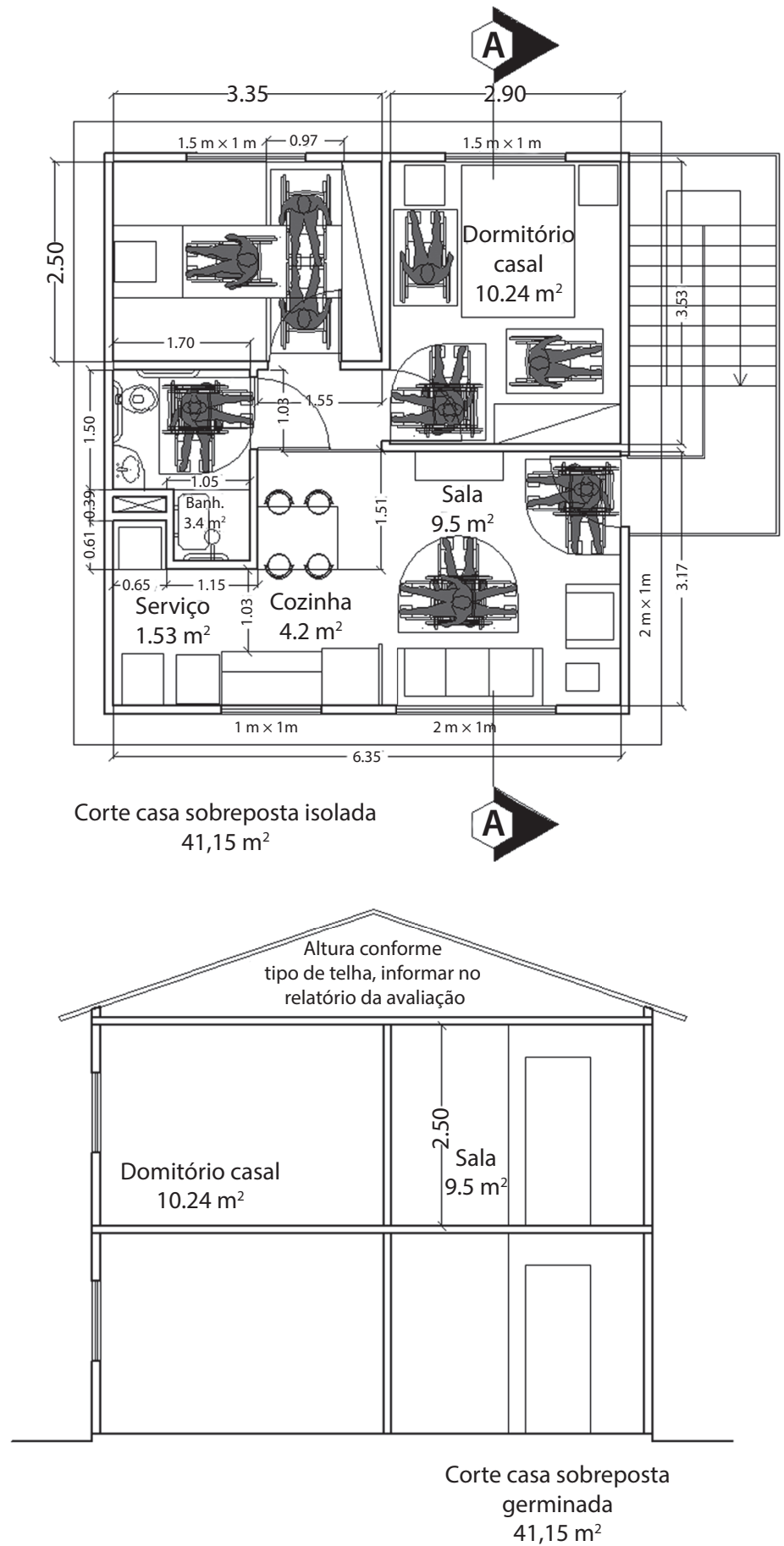

Figura A3. Projeto de casa sobreposta. 

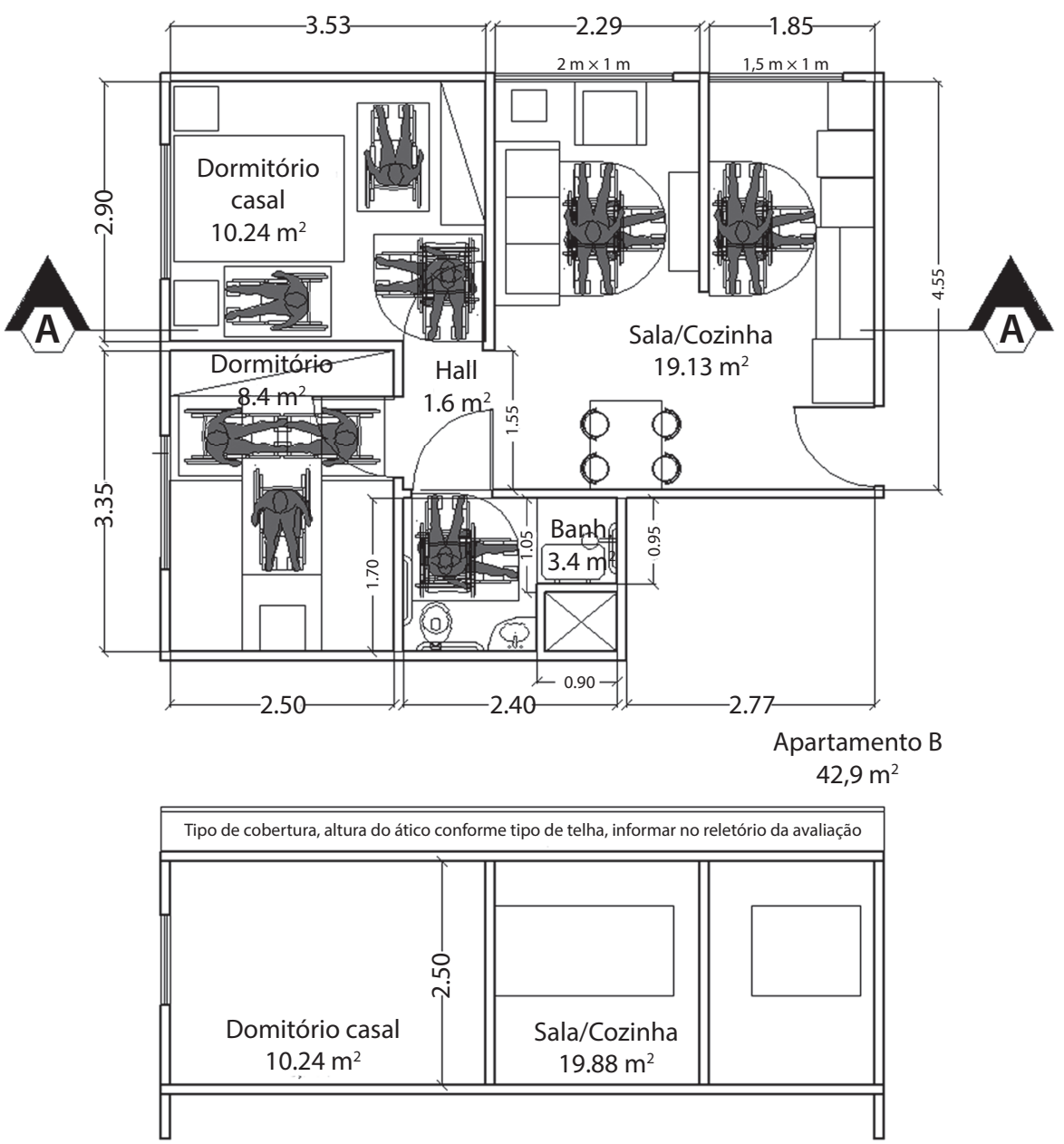

Corte

Apartamento B

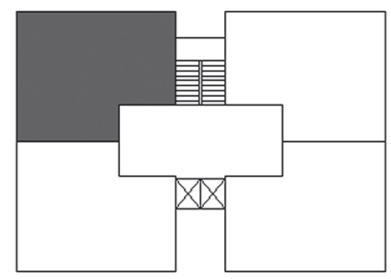

Figura A4. Projeto de apartamento. 


\section{Referências}

AKUTSU, M. Método para avaliação do desempenho térmico de edificaçóes no Brasil. 1998. 150 p. Tese (Doutorado) - Faculdade de Arquitetura e Urbanismo, Universidade de São Paulo, São Paulo, 1998.

AKUTSU, M.; VITTORINO, F. Proposta de procedimentos para o tratamento de dados climáticos. In: Encontro Nacional de Normalização Ligada ao Uso Racional de Energia e ao Conforto Ambiental em Edificaçôes, 1990. Florianópolis. Anais... Florianópolis, 1991.

ASSOCIAÇÃO BRASILEIRA DE NORMAS TÉCNICAS - ABNT. NBR 15220: Desempenho Térmico de Edificações. Rio de Janeiro, 2008.

ASSOCIAÇÃO BRASILEIRA DE NORMAS TÉCNICAS - ABNT. NBR 15575: Edifícios Habitacionais - Desempenho. Rio de Janeiro, 2013.

ALFONSI, R.R.; SENTELHAS, P.C. Estimativa da temperatura do solo através da temperatura do ar em abrigo meteorológico. Revista Brasileira de Agrometeorologia, Santa Maria, v. 4, n. 2, p. 57-61, 1996.

AZEVEDO, T. R.; GALVANI, E. Ajuste do ciclo médio mensal horário da temperatura do solo em função da temperatura do ar. Revista Brasileira de Agrometeorologia, Santa Maria, v. 11, n. 2, p. 123-130, 2003.

CENTRO DE REFERÊNCIA PARA ENERGIA SOLAR E EÓLICA SÉRGIO BRITO - CRESESP-CEPEL. Dados de radiaçáo solar. Acesso em: 2015.

COMPANHIA DE DESENVOLVIMENTO HABITACIONAL E URBANO CDHU. Caderno de Tipologias. 1997.

COSTA, A.O.L.; GODOY, H. Contribuição para o conhecimento do clima do solo de Ribeirão Preto, SP. Bragantia, Campinas, v. 21, p. 689-742, 1962.

FLORIDES, G.; KALOGIROU, S. Measurements of Ground Temperature at Various Depths, 3rd International Conference on Sustainable Energy, 2004. Nottingham. Proceedings... Nottingham, 2004. Technologies on CD-ROM, Nottingham, UK.

GOEDERT, C.O. Temperatura do planossolo em Pelotas, RS. Pesquisa Agropecuária Brasileira, Brasília, v. 6, p. 9-11, 1971.

INSTITUTO NACIONAL DE METEOROLOGIA - INMET. Normais Climatológicas do período de 1961 - 1990. http://www.inmet.gov.br/portal/. Acesso em: jan. 2015.

KUSUDA, T.; ACHENBACH, P. R. Earth temperature and termal diffusivity at selected stations in the United States. ASHRAE Transactions, v. 71, Part. 1, 1965.

VILELA, M. M. Estudo de método experimental para determinar a potencialidade do uso de energia geotérmica a baixa profundidade. 2004. 278 p. Tese (Doutorado) Programa Interunidades de pós-graduação em energia. Universidade de São Paulo, São Paulo, 1998.

UNITED STATES DEPARTMENT OF ENERGY. ENERGYPLUS, Energy Simulation Software - Energy Efficiency and Renewable Energy - Building Technologies Program. https://energyplus.net/ - Acessos em: jan. 2015 e fev. 2017. 